\title{
Water subsidies from mountains to deserts: their role in sustaining groundwater-fed oases in a sandy landscape
}

\author{
E. G. Jobbágy, ${ }^{1,2,6}$ M. D. Nosetto, ${ }^{1,2,3}$ P. E. Villagra,${ }^{4}$ and R. B. Jackson ${ }^{5}$ \\ ${ }^{1}$ Grupo de Estudios Ambientales-IMASL, CONICET, San Luis, Argentina \\ ${ }^{2}$ Departamento de Agronomia - FICES, Universidad Nacional de San Luis, San Luis, Argentina \\ ${ }^{3}$ Cátedra de Climatología Agrícola, Facultad de Ciencias Agropecuarias, Universidad Nacional de Entre Ríos, Argentina \\ ${ }^{4}$ Instituto Argentino de Nivología, Glaciología y Ciencias Ambientales, CCT-CONICET, Mendoza, Argentina \\ ${ }^{5}$ Department of Biology and Nicholas School of the Environment and Earth Sciences, Duke University, Durham, North Carolina, USA
}

Abstract. In arid regions throughout the world, shallow phreatic aquifers feed natural oases of much higher productivity than would be expected solely from local rainfall. In South America, the presence of well-developed Prosopis flexuosa woodlands in the Monte Desert region east of the Andes has puzzled scientists for decades. Today these woodlands provide crucial subsistence to local populations, including descendants of the indigenous Huarpes. We explore the vulnerability and importance of phreatic groundwater for the productivity of the region, comparing the contributions of local rainfall to that of remote mountain recharge that is increasingly being diverted for irrigated agriculture before it reaches the desert. We combined deep soil coring, plant measurements, direct water-table observations, and stableisotopic analyses $\left({ }^{2} \mathrm{H}\right.$ and $\left.{ }^{18} \mathrm{O}\right)$ of meteoric, surface, and ground waters at three study sites across the region, comparing woodland stands, bare dunes, and surrounding shrublands. The isotopic composition of phreatic groundwaters $\left(\delta^{2} \mathrm{H}:-137 \% \pm \pm 5 \%\right)$ closely matched the signature of water brought to the region by the Mendoza River $(-137 \% \pm 6 \%$ ), suggesting that mountain-river infiltration rather than in situ rainfall deep drainage $(-39 \% \pm 19 \%$ o was the dominant mechanism of recharge. Similarly, chloride mass balances determined from deep soil profiles $(>6 \mathrm{~m})$ suggested very low recharge rates. Vegetation in woodland ecosystems, where significant groundwater discharge losses, likely $>100 \mathrm{~mm} / \mathrm{yr}$ occurred, relied on regionally derived groundwater located from 6.5 to $9.5 \mathrm{~m}$ underground. At these locations, daily water-table fluctuations of $\sim 10 \mathrm{~mm}$, and stable-isotopic measurements of plant water, indicated groundwater uptake rates of $200-300 \mathrm{~mm} / \mathrm{yr}$. Regional scaling suggests that groundwater evapotranspiration reaches $18-42 \mathrm{~mm} / \mathrm{yr}$ across the landscape, accounting for 7$17 \%$ of the Mendoza River flow regionally. Our study highlights the reliance of ecosystem productivity in natural oases on Andean snowmelt, which is increasingly being diverted to one of the largest irrigated regions of the continent. Understanding the ecohydrological coupling of mountain and desert ecosystems here and elsewhere should help managers balance production agriculture and conservation of unique woodland ecosystems and the rural communities that rely on them.

Key words: algarrobo woodlands; arid oasis; central Monte Desert, western Argentina; Cordillera de los Andes; groundwater recharge/discharge; Larrea shrublands; Mendoza River; Monte Desert; phreatophytes; Prosopis flexuosa woodlands; Telteca Provincial Reserve (Argentina).

\section{INTRODUCTION}

Shallow groundwater can sustain the productivity of arid ecosystems at much higher levels than would be expected solely from local rainfall (Freeze and Cherry 1979, Eamus et al. 2006, Jackson et al. 2009). Groundwater-fed upland ecosystems are important hotspots of biodiversity and economic activity, including those in the deserts of Australia, North America, and Asia (e.g., Devitt et al. 2002, Eamus et al. 2006,

Manuscript received 5 August 2009; revised 9 June 2010; accepted 9 June 2010. Corresponding Editor: D. S. Schimel.

6 Present address: Grupo de Estudios Ambientales, IMASL - UNSL, Ejército de los Andes 950-5700, San Luis, Argentina. E-mail: jobbagy@unsl.edu.ar
Sanderson and Cooper 2008). Understanding the sources of recharge that maintain such ecosystems is of critical importance to the diverse people that depend on them, typically rural communities adapted to these particularly harsh environments. For instance, the relatively high-productivity woodlands of the Monte Desert have provided local peoples with crucial subsistence for centuries (Montaña et al. 2005, Torres 2008). However, the source of the water that maintains these ecosystems is uncertain. Here we explore the reliance of these woodlands on their underlying aquifers, identifying their sources of recharge and quantifying their overall contribution to the regional water balance of the desert. 
Shallow aquifers can be sustained by local or distant recharge sources. In most arid regions, evapotranspiration recycles essentially all precipitation inputs back to the atmosphere, resulting in negligible recharge locally (Scanlon et al. 2006). Important exceptions occur in locations that have sandy or rocky soils, such as sand dunes and fractured rock outcrops, low or degraded vegetation cover, highly seasonal and intense precipitation regimes, or extensive lateral flow or run-on; in such cases at least some deep drainage into the saturated zone will eventually occur (Scanlon and Goldsmith 1997, Athavale et al. 1998, Seyfried et al. 2005, Small 2005, Gates et al. 2008). More-distant sources of recharge are particularly significant in arid regions located downstream of water-yielding mountains (Wilson and Guan 2004). For example, the occurrence of shallow water tables, wetlands, and lakes in the lowest positions of many sand dune landscapes has been attributed to mountain snowmelt in locations such as the Great Sand Dunes of Colorado (USA) (Wurster et al. 2003) and the Barain Jaram and Taklamakan deserts in China (Thomas et al. 2000, Chen et al. 2004, Gates et al. 2008).

From a water-balance perspective, locally derived groundwater that becomes accessible to plants does not represent a new net water contribution but rather an opportunity to consume unused rainfall redistributed in space (such as from dune tops to interdunes) or time (from wet years to dry years). In contrast, more-distant sources of recharge can increase the overall productivity of a landscape as well as its vulnerability to hydrologic, climatic, and ecological change upstream. In sandy deserts flanked by high mountain ranges, local rainfall inputs and remote water subsidies can both be significant sources of groundwater recharge, but remote water sources are more vulnerable to human diversion and use through irrigation (Milner et al. 2009).

Groundwater use by plants typically declines as water-table levels drop, both in space along topographic gradients (Zencich et al. 2002, Gries et al. 2003, Nosetto et al. 2009), and through time, such as seasonal shifts in water-table depth (Stromberg et al. 1992, Naumburg et al. 2005, Cooper et al. 2006). Although shrubs and tree species can have maximum rooting depth of many meters (Canadell et al. 1996, Schenk and Jackson 2002), and some observations suggest groundwater uptake below $20 \mathrm{~m}$ of depth (Haase et al. 1996, Gries et al. 2003), we are unaware of significant groundwater supply to desert ecosystems with water tables that are $>10 \mathrm{~m}$ deep (Nichols 1994, Zencich et al. 2002). Most plants show a dynamic and facultative reliance on groundwater according to rainfall variability, with soil moisture preferred over groundwater when available (Engel et al. 2005). Knowledge of the groundwater reliance of plant species and, more importantly, whole ecosystems, should be useful in shaping the development of management strategies for arid oases.

The central Monte Desert occupies a vast territory east of the Andes Cordillera in Argentina. Although sparsely covered Larrea shrublands dominate the widespread sand dune landscapes, interdune areas often host Prosopis woodland ecosystems of high biological and economic value (Rundel et al. 2007). The presence of these woodlands appears to be spatially associated with shallow $(<10 \mathrm{~m})$ water tables (Gonzalez Loyarte et al. 2000), yet their degree of reliance on groundwater and its recharge sources is unknown. Local recharge may occur because soils are sandy, rainfall inputs are intense and are concentrated in summer, and the vegetation has been subject to overgrazing and logging for almost a century (Abraham et al. 2009). Remote recharge sources, however, could also be important, since several rivers carry snowmelt water to the region from high-elevation watersheds in the Andes.

In this paper we explore the interaction of ecosystems and groundwater in the central Monte Desert, examining the source of phreatic groundwater and its uptake by plants. Six questions guided our work at regional, landscape, and local scales. At regional scales we asked, (1) What are the contributions of local rainfall and mountain snowmelt to recharge? and (2) How much groundwater is discharged through evapotranspiration? At the landscape scale, we asked (3) What are the patterns of vertical water exchange between ecosystems and phreatic aquifers across the sand dunes landscapes? and (4) How do these patterns change across topographic positions and plant cover? Finally, more locally we asked (5) How stable are water-table depths across seasons and years? and (6) How does groundwater reliance vary among plant species and seasons? To address these questions we combined stable-isotopic analyses, plant measurements, soil and sediment coring, and direct measurements of water-table depth and fluctuations. At the regional scale we investigated the sources of groundwater recharge by characterizing the stable-isotopic composition of water from rainfall, snowmelt-fed rivers, phreatic groundwater, and unsaturated soil, achieving a regional estimate of groundwater evapotranspiration by scaling up a suite of detailed observations. At the landscape scale we evaluated the direction and magnitude of vertical water exchange by measuring moisture contents, isotopic compositions, and chloride concentrations in soil and sediment profiles across multiple topographic positions. Finally, at the local stand scale we monitored water-table levels and used stable isotopes to assess the reliance of different plant species on groundwater uptake throughout the year.

\section{Materials And Methods \\ Study region and sites}

The central Monte is a temperate desert that spans $\sim 120000 \mathrm{~km}^{2}$ of western Argentina. Its vast sandy aeolian plains host shrublands dominated by Larrea divaricata. In some areas, however, low landscape positions are occupied by larger trees dominated by Prosopis flexuosa. Located next to one of the highest 

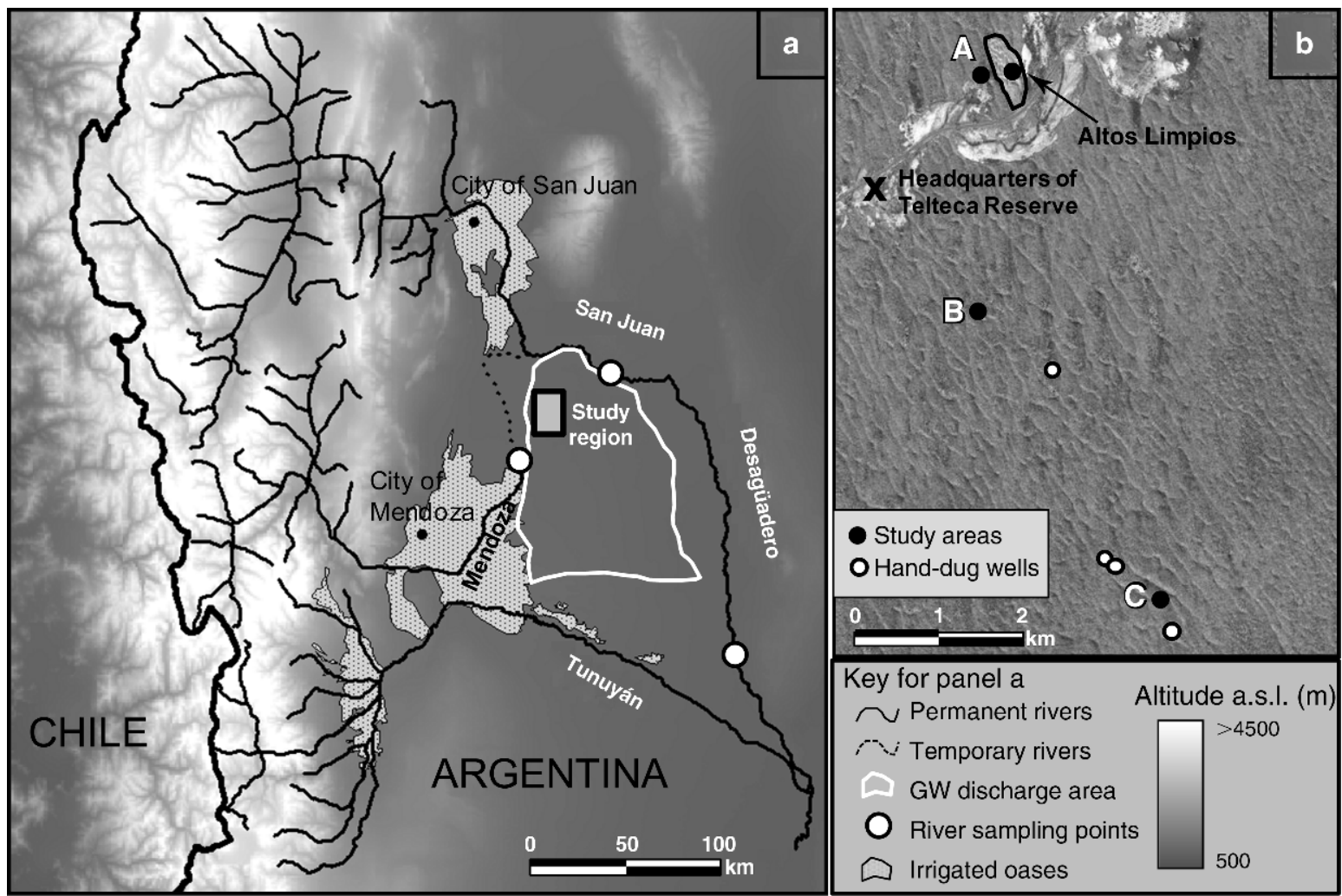

FIG. 1. The study region. (a) Regional map showing the watersheds of the San Juan, Mendoza, and Tunuyán Rivers from their origin in the high Andes to their convergence into the Desaguadero. Three of the largest irrigated areas of South America are fed by these rivers on the foot slope of the Andes (gray areas). Our research focused on the sand dune territory located downstream of the lower Mendoza River (white line). (b) A detailed view of our study region based on high-resolution Google Earth imagery indicates the location of study sites. Hand-dug wells are built by local people and are usually associated with homesteads. Precipitation amount and chemistry were recorded at the headquarters of the Telteca Reserve. "Altos Limpios" is a bare-dune area with no vegetation. A currently dry riverbed with SW-NE direction, corresponding to the ancient and abandoned trajectory of the Mendoza River can be seen in the image.

sections of the Andean Cordillera, the central Monte receives large inflows of snowmelt from the San Juan, Mendoza, and Tunuyán Rivers (mean annual flow for 1954-2004: 58, 45, and $29 \mathrm{~m}^{3} / \mathrm{s}$, respectively; Subsecretaria de Recursos Hídricos 2004). These three rivers also sustain one of the largest irrigated agricultural regions in South America, $\sim 7000 \mathrm{~km}^{2}$ of vineyards and olive orchards (Fig. 1).

Our study was carried out in the Telteca Provincial Reserve and surrounding areas, an aeolian sandy plain near the lower Mendoza river and downstream of its major irrigated area (Fig. 1a). Transverse dunes oriented NNW-SSE and discontinuous valleys create elevation gradients of $8-20 \mathrm{~m}$ between interdune lowlands and dune crests. Dating of sands close to the study area indicate a late Quaternary origin for these dune fields with several stabilization and remobilization periods in the last five millennia (Tripaldi and Forman 2007). The water table in the lowlands is located 6-15 m below the surface and no permanent surface water is present in the dune territory. Soils are poorly developed Entisols with $>95 \%$ sand. In spite of the current water-table depths, some lowlands show an accumulation of evaporites (calcite and gypsum) and, in a few cases, small shell fragments that suggest periods of higher water tables or even surface-water availability in the past. At the bottom of some lowlands, an accumulation of finetextured materials, mostly evaporites, is observed at the surface but not at depth. These fine materials restrict infiltration and support the formation of ephemeral ponds in the lowest positions after large rain events.

Current precipitation at the headquarters of the Telteca Provincial Reserve is $156 \mathrm{~mm} / \mathrm{yr}$ (1972-2007 average), $>80 \%$ of which takes place in the austral summer and fall between October and March. PenmanMonteith potential evapotranspiration approaches 1300 $\mathrm{mm} / \mathrm{yr}$, and the aridity index (precipitation/potential evapotranspiration) is $0.12 \quad(1960-1990$, Climate Research Unit database; New et al. 2002). Mean annual temperature is $18.5^{\circ} \mathrm{C}$, with minimum and maximum temperatures reaching a few degrees below zero in winter to at least $47^{\circ} \mathrm{C}$ in summer.

High and intermediate landscape positions are dominated by Larrea divaricata, Tricomaria usillo, Bulnesia 
retama, and Atriplex lampa accompanied by small individuals (height $<3 \mathrm{~m}$ ) of Prosopis flexuosa and a sparse layer of the grass Panicum urvilleanum. Lowlands with a typical area of 1-10 ha are generally covered by denser and taller formations of the tree species Prosopis flexuosa, Bulnesia retama, and Geoffrea decorticans (height, 5-10 m) (Villagra et al. 2005, Alvarez et al. 2006) accompanied by most of the species found in higher topographic positions (Gonzalez Loyarte et al. 2000).

Local settlers live in homesteads or "puestos" located in interdune positions and based around hand-dug wells that reach the water table and supply both people and livestock with water. The area around a given puesto is grazed by goats and, to a lesser extent, cattle. More than 80 locations with single or clustered puestos are found across the sand dune territory of the study region (Torres 2008). Large Prosopis trees growing in the lowlands not only supply goats with a major forage source, including seed pods and foliage, but also supply people with timber for construction and well casings as well as food for people, including flour from seeds, and syrup and beverages from seedpod carpels. Although the sandy landscape is stable and the dunes are stabilized by the current vegetation, a few areas of bare dunes reach up to 50 ha in size, as in the Altos Limpios area (Fig. 1b).

Our observations were focused on three study sites of vegetated dunes (Fig. 1b). Sites A and B have had less grazing pressure since the creation of the reserve in 1986 , whereas site $\mathrm{C}$ has been subject to more intensive grazing that is typical for the region. Site A also included a bare dune zone (Altos Limpios) without plants to compare to the adjacent stable, vegetated landscape. At each site we sampled soil profiles along transects covering full toposequences. We sampled soil and sediments extensively to the water table at lowland positions, using the resulting boreholes for longer-term monitoring of groundwater depth and chemistry at each location. We complemented our regional assessment of the stable-isotopic composition of rainfall and surface waters at each site with a more detailed subset of data for soils at study sites $\mathrm{A}$ and $\mathrm{C}$ and for plants at study site C.

\section{Stable-isotope survey}

To explore the different contributions of local rainfall and distant Andean snowmelt to groundwater recharge, and to trace its consumption by natural vegetation, we analyzed the stable-isotopic composition of rainfall, rivers, phreatic groundwater, ephemeral rain-fed ponds, soil moisture, and plant xylem water between May 2005 and May 2008. The lowest sections of the Mendoza and San Juan Rivers were sampled on five occasions of contrasting flow conditions, just upstream of the study region (Fig. 1a). Phreatic groundwater was sampled once at four hand-dug wells 6.5 to $7.5 \mathrm{~m}$ below the surface and repeatedly at the four boreholes that we established for this study. Water from 10 rainfall events was collected at the headquarters of the Telteca Provincial Reserve, and these data were supplemented with 54 additional rainfall events (November 1982 to November 1999) from the GNIP database (IAEA/ WMO 2006) for the city of Mendoza, $90 \mathrm{~km}$ southwest of our study region. We sampled two ephemeral ponds in lowlands one day after a large rainfall event in January 2007. All water samples were filtered $(0.45 \mu \mathrm{m})$ and sealed in vials for analysis. Rainfall collected at the Telteca Reserve was also analyzed for chloride concentrations using ion chromatography to help determine $\mathrm{Cl}$ inputs for our recharge estimates using soil and sediment chloride profiles.

Soil and sediment samples from lowland and upland boreholes at study sites $\mathrm{A}$ and $\mathrm{C}$ were saved for isotopic analysis. At study site $\mathrm{C}$ we sampled plant xylem sap water in two seasons. Early sampling took place shortly before Prosopis trees started to shed their leaves at the end of a relatively wet growing season ca. 25 May 2005 (hereafter called the "wet season"). The second sampling took place at the end of the dry season before the onset of rain on 3 November 2006; although the rainy period had not started, the first new leaves of Prosopis trees were already fully expanded. At each sampling date and topographic position we sampled five individuals of the target species by cutting stems $2-10 \mathrm{~mm}$ wide, 2 to 3 stems per individual. Both soil samples and plant stems were immediately sealed in $10-\mathrm{mL}$ vials. Water from these samples was extracted using an azeotropic distillation procedure (Ehleringer et al. 1991). All water samples were analyzed at the Duke University Environmental Stable Isotope laboratory (Durham, North Carolina, USA) using a Finnigan MAT Delta Plus XL continuous flow mass spectrometer. All isotopic values are reported as per mil delta $(\delta \%$ ) relative to $\mathrm{V}$ SMOW (Vienna standard mean ocean water). Calibration against NIST / IAEA reference materials V-SMOW and SLAP (standard light Antarctic precipitation) and two or more internal standards were performed. Typical precision is approximately $\pm 1.5 \%$ and $0.1 \%$ at one SD for ${ }^{2} \mathrm{H}$ and ${ }^{18} \mathrm{O}$, respectively.

\section{Soil and sediment sampling and estimates of water transport}

To evaluate ecosystem-aquifer water exchange at our three study sites, we obtained soil moisture and chloride profiles. We established transects across two contiguous dune crests covering a full toposequence of seven positions (east crest, east midslope, east footslope, bottom, west footslope, west midslope, west crest) sampled down to $2.5 \mathrm{~m}$ of depth. For a more complete vertical description of soil and sediment profiles, we also sampled lowlands down to the water table at 6-9.5 m of depth and dune tops down to $5 \mathrm{~m}$ of depth. In all cases we used hand augers (10 cm in diameter) and applied a PVC casing when needed to avoid borehole clogging by collapsed sand. Full samples from 50-cm-depth intervals 
were immediately mixed in the field, subsampled and stored in double plastic bags for moisture and chloride analysis as well as in sealed vials for isotopic analysis. Moisture content was determined gravimetrically one to four days after sampling (oven drying method, Gardner 1986). Chloride concentrations were measured on 1:2 soil-to-water extracts using a solid-state ion-selective electrode (Frankenberger et al. 1996) and a five-point calibration scheme that included additional references and spikes. Standards calibrated with more precise ionchromatography equipment suggested a detection limit of $0.3 \mathrm{ppm}$ and typical precision ranging from $\sim 5 \%$ to $2 \%$ of the readings as concentrations became higher. Soil texture was characterized for five 50 -cm-deep intervals distributed throughout each profile using the Bouyocus method (Gee and Bauder 1986), complemented with sieving for the separation of sand particles. Soils were relatively homogeneous within and among soil profiles with the exception of topsoil samples $(0-50 \mathrm{~cm}$ deep) in vegetated lowlands, which had clay + silt contents of $7-$ $10 \%$; all the rest of the analyzed samples had clay + silt contents $<5 \%$, with the sand fraction being dominant (80-99\%, primarily fine sand particles $0.05-0.125 \mathrm{~mm}$ in size).

Chloride profiles provide qualitative information on the dominant vertical direction of ecosystem-groundwater exchange. In addition more quantitative estimates of recharge and discharge rates can be attempted if atmospheric chloride inputs can be constrained. For this purpose we approximated atmospheric chloride inputs based on our rainfall concentration measurements $(n=$ 10 , mean $=0.35 \mathrm{mg} / \mathrm{L}$ ), long-term average rainfall rates for the site $\left(150 \mathrm{~L} \cdot \mathrm{m}^{-2} \cdot \mathrm{yr}^{-1}=\mathrm{mm} / \mathrm{yr}\right)$ and a twofold magnification factor applied to accounted for dry deposition inputs (Scanlon et al. 2005), which yielded a figure of $105 \mathrm{mg} \mathrm{Cl} \cdot \mathrm{m}^{-2} \cdot \mathrm{yr}^{-1}$. Although our $\mathrm{Cl}^{-}$ deposition estimates have large uncertainty, they were useful to approximate the order of magnitude of recharge rates and, more importantly, the relative differences between landscape positions.

Recharge fluxes in upland areas were approximated using chloride concentrations in the vadose zone based on the assumption that (a) chloride transport is well approximated by piston flow, (b) all inputs to the ecosystem originate from atmospheric deposition, with rock-weathering supply being negligible, and (c) plant uptake and storage in biomass and organic matter were negligible components of the chloride balance (Allison et al. 1985). This conservative behavior enables the calculation of the residual moisture flux (Phillips 1994):

$$
J_{\mathrm{R}}=D_{\mathrm{cl}} \times C_{\mathrm{cl}}^{-1} \times 1000(\mathrm{~mm} / \mathrm{m})
$$

where $J_{\mathrm{R}}$ is the net downward residual flux at the depth of measurement $(\mathrm{mm} / \mathrm{yr}), D_{\mathrm{cl}}$ is the $\mathrm{Cl}^{-}$deposition rate $\left(\mathrm{g} \cdot \mathrm{m}^{-2} \cdot \mathrm{yr}^{-1}\right)$, and $C_{\mathrm{cl}}$ is the measured $\mathrm{Cl}^{-}$concentration in the soil water $\left(\mathrm{g} / \mathrm{m}^{3}\right)$. The value of $C_{\mathrm{cl}}$ was determined by plotting cumulative $\mathrm{Cl}^{-}$content (mass $\mathrm{Cl}^{-}$per unit volume of soil) with depth against cumulative water content (volume water per unit volume soil) at the same depths. In all cases straight-line segments were found once the top meter was discarded. The slope of these plots was used as the $\mathrm{C}_{\mathrm{cl}}$ value of Eq. 1 (Phillips 1994). We also calculated the residence time of the soil water $\mathrm{Cl}^{-}$by dividing $\mathrm{Cl}^{-}$storage down to the depth of interest by the annual $\mathrm{Cl}^{-}$deposition rates according to Phillips (1994):

$$
t_{z}=\int_{(0-z)} \theta C_{\mathrm{cl}} \times d z / D_{\mathrm{cl}}
$$

where $t_{z}$ is the transport time of the soil-water $\mathrm{Cl}^{-}$to depth $z(\mathrm{yr})$, and $\theta$ is the volumetric water content $\left(\mathrm{m}^{3} /\right.$ $\mathrm{m})$, calculated at our sites based on gravimetric moisture concentrations $(\mathrm{g} / \mathrm{g})$ adjusted by bulk density $\left(\mathrm{g} / \mathrm{m}^{3}\right)$ measurements at each sampling interval. In lowland sites, where the water table is closer to the surface and evapotranspirative discharge can take place, chloride accumulation in the vadose zone can exceed the amounts attributable to atmospheric deposition, thanks to the contributions from groundwater. In these situations Eq. 2 can yield extremely long turnover rates that exceed the age of sediments, providing evidence of net groundwater discharge (Jobbágy and Jackson 2007).

\section{Groundwater monitoring}

The boreholes that we maintained after our deep soil and sediment sampling at vegetated lowlands in study sites $\mathrm{A}, \mathrm{B}$, and $\mathrm{C}$ and at the bare lowland position in study site A were permanently cased with PVC pipes and used to monitor groundwater depth and chemistry. Well casing was introduced $\sim 0.5 \mathrm{~m}$ below the water table into the saturated zone. Water-table depth from the surface in each well was monitored manually at 1-4 month intervals for at least two full growing seasons. In addition, we installed automated pressure transducers with built-in dataloggers (HOBO water level logger; Onset Computer Corporation, Bourne, Massachusetts, USA) to record groundwater level with higher frequency (every 30 minutes) and vertical resolution (less than $\pm 0.5 \mathrm{~cm}$ ) for several periods in different wells. In all cases water depth was corrected after discounting barometric pressure, which was measured with similar sensors installed in the surface. Estimates of groundwater discharge were obtained from daily fluctuations of water-table levels (Engel et al. 2005, Loheide et al. 2005, Nosetto et al. 2007), often observed during the growing season in the vegetated lowlands. To obtain daily discharge values we used the estimates of specific yield (groundwater discharged per unit of water-table level decline) under fluctuating conditions proposed by Loheide et al. (2005) for sandy soils $(0.3 \mathrm{~mm} / \mathrm{mm})$. We also sampled groundwater on five occasions with bailer samplers after purging water stored in the well casing. Samples were analyzed for chloride, electrical conductivity, and stable-isotope composition. 


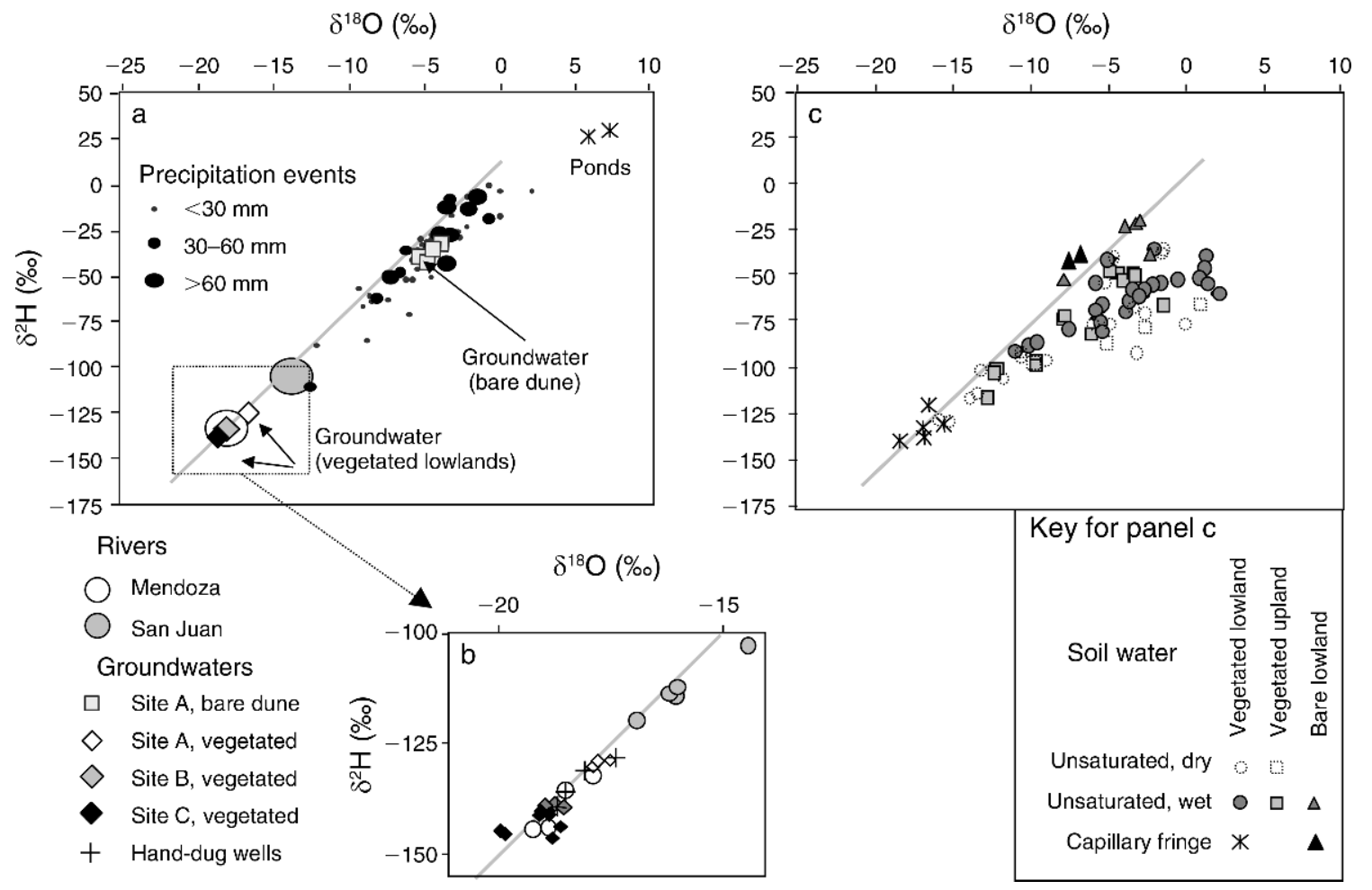

FIG. 2. Natural abundance of hydrogen and oxygen stable isotopes in water samples from the central Monte Desert. (a) Meteoric, surface, and ground waters; all groundwater samples are pooled. Precipitation events, differentiated by their size, were sampled at the town of Mendoza (IAEA/EMO 2006) and at the study area, in Telteca. The Mendoza and San Juan Rivers were sampled at their lowest sections before entering the study area, and large circles indicate the average of all sampling dates for these rivers. Average across-date values for groundwater collected in boreholes at study sites and in existing hand-dug wells are represented with diamonds. Two temporary ponds were sampled at site A. (b) Detailed isotopic composition of river and groundwater samples indicating values for each sampling date; groundwater samples are segregated. (c) Soil water. Samples are grouped according to landscape situations and differentiated by their vertical position in the profile (unsaturated zone vs. capillary fringe) and their gravimetric moisture content (dry, $<1.3 \%$; wet, $>1.3 \%$ ) in the case of the unsaturated zone. In all plots the global meteoric water line is indicated (Craig 1961).

\section{Remote sensing}

To provide an independent characterization of groundwater subsidies to woodland ecosystems, we explored their imprint on primary productivity patterns using the MODIS (moderate-resolution imaging spectroradiometer) EVI (enhanced vegetation index) product MOD13Q1 (Huete et al. 2002). This radiometric index is based on the reflective properties of the surface on visible and near-infrared wavelength bands and represents a 16-day composite with a spatial resolution of 250 $m$. EVI values increase with the fraction of photosynthetically active radiation intercepted by vegetation and are sensitive to a small change of vegetation activity in time and space (Huete et al. 2002, Xiao et al. 2005). Based on fine-resolution satellite images from the Google Earth online system and Landsat satellite data, we selected six sites $(250 \times 250 \mathrm{~m})$ with more than $80 \%$ of woodland coverage. At each site we additionally selected an adjacent upland stand characterized by $<20 \%$ and $>80 \%$ of woodland and shrubland coverage, respectively, for comparison. We also included a baredune stand as a baseline reference. For each stand, EVI data covering 184 dates between 2001 and 2008 were analyzed. In order to evaluate the relative greenness increase in lowlands compared to uplands, we subtracted from both situations a baseline, non-vegetated EVI value obtained from bare-dune stands

\section{RESUlTS}

\section{Regional water signatures and recharge sources}

Local precipitation and Andean river waters had strongly contrasting isotopic compositions, and groundwater samples closely matched river-water signatures across the sites (Fig. 2a). Precipitation events sampled in the town of Mendoza $(n=54)$ within the GNIP initiative (IAEA/WMO 2006) and in Telteca $(n=10)$ by our team had relatively heavy isotopic compositions with mean $\delta^{18} \mathrm{O}$ values of $-5.38 \%$ and mean $\delta^{2} \mathrm{H}$ values of $-38.6 \%$. These observations are consistent with summer storms occurring at low elevations $(<1000 \mathrm{~m}$ above sea level) and fed by Atlantic and continental moisture sources from lower latitudes (Carril et al. 1997). In contrast, the Mendoza and San Juan Rivers from the Andes had much lighter isotopic compositions averaging $-18.20 \%$ 

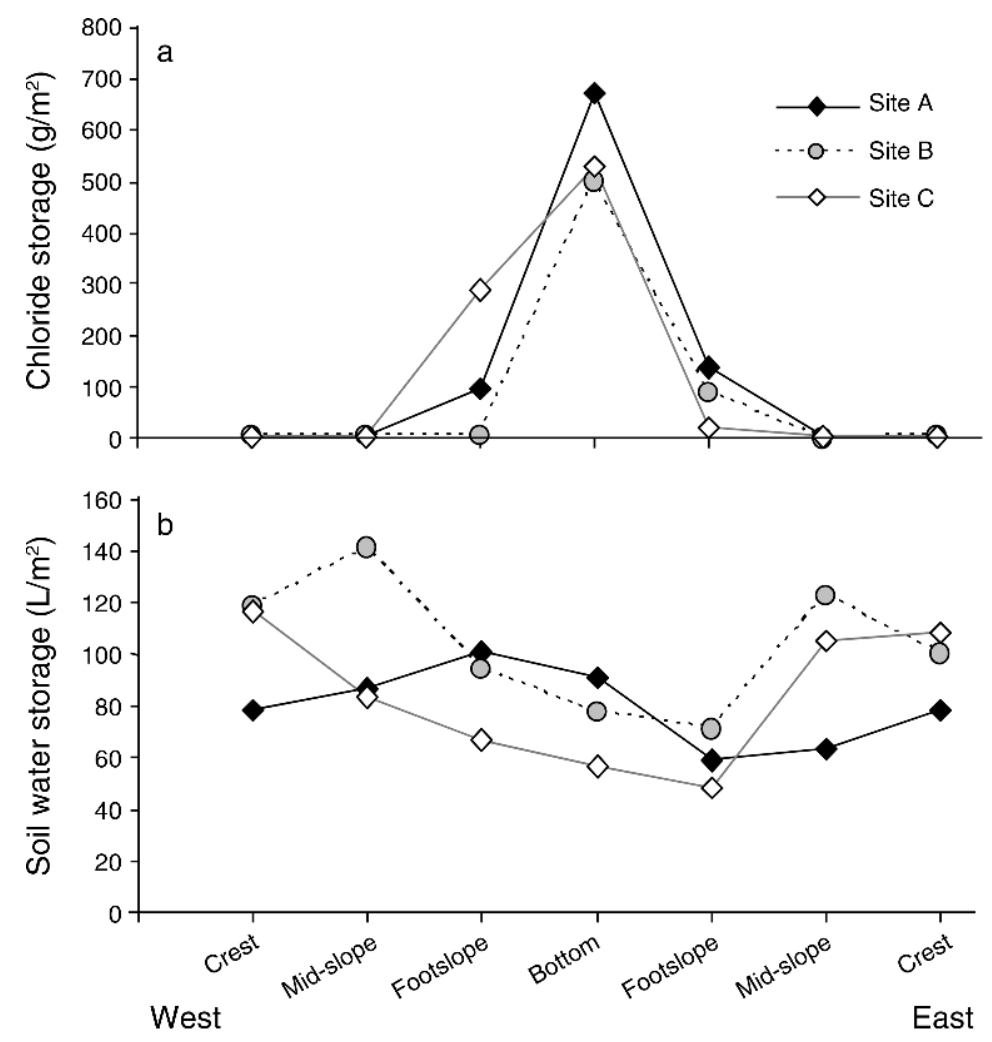

FIG. 3. Soil transects along full dune toposequences at three study sites. (a) Soil chloride storage down to $2.5 \mathrm{~m}$ depth. (b) Soil water storage down to $2.5 \mathrm{~m}$ depth.

for $\delta^{18} \mathrm{O}$ and $-136.9 \%$ for $\delta^{2} \mathrm{H}$ (four dates) for the Mendoza River, and $-14.37 \%$ for $\delta^{18} \mathrm{O}$ and $-111.2 \%$ for $\delta^{2} \mathrm{H}$ (five dates) for the San Juan River, values that were quite stable across sampling dates (Fig. 2b). The light isotopic composition of these rivers reflects their origin in high-elevation $(>3000 \mathrm{~m}$ ) watersheds in the main range of the Cordillera, where precipitation is dominated by winter snow events fed by Pacific moisture sources from higher latitudes (Masiokas et al. 2006).

Groundwater in boreholes at sites B and $\mathrm{C}$ and in our additional wells closely matched the composition of the Mendoza River at all sampling dates, confirming that groundwater at the sites comes from Andean snowmelt rather than from local rainfall (Fig. 2). Groundwater in the vegetated interdune at site A was slightly enriched in heavier isotopes but still quite close to the signature of Andean river water and distinct from local precipitation events (Fig. 2a,b). Groundwater did not match the isotopic signature of two temporary ponds sampled after a large rainfall event $(51 \mathrm{~mm}, 25$ December 2007) in the fine-textured bottoms of the vegetated interdunes of sites A and C (30-45 $\mathrm{m}$ away from the sampling boreholes, Fig. 2a), indicating little or no contributions of localized recharge from runoff. Isotopic profiles in vegetated lowlands showed a groundwater-fed capillary zone and isolated rainfall-fed zones with some degree of evaporative enrichment (see the drift to the right of the meteoric water line, Fig. 2c). These results suggest that under current conditions groundwater abundance strongly depends on Andean snowmelt waters rather than local rainfall. In contrast with vegetated areas, the isolated bare dune sampled at site A showed groundwaters of much heavier isotopic composition that matched local rainfall events, suggesting local recharge at that single location without plants (Fig. 2a). Soil moisture in the capillary fringe (i.e., the zone of upward groundwater transport above the water table) and the unsaturated zone was also isotopically similar to local rainfall (Fig. 2c).

\section{Landscape patterns of water exchange}

Soil transects across dune toposequences at all three sites showed consistently higher chloride storage at dune bottoms $(P<0.05$, paired $t$ test $)$ and, to a lesser extent, at intermediate foot slopes $(P<0.1)$ (Fig. 3). Maximum pore water chloride values were $>13 \mathrm{~g} / \mathrm{L}$ at all dune bottoms, $0.05-22 \mathrm{~g} / \mathrm{L}$ at foot slopes, and $<0.06 \mathrm{~g} / \mathrm{L}$ at the higher topographic positions, with total chloride storage down to $2.5 \mathrm{~m}$ of depth following the same trends (Fig. 3a). Soil moisture storage along transects did not show significant contrasts across positions except that the west foot slopes were significantly drier than crests and mid slopes in general $(P<0.05$, paired $t$ test, Fig. 3b). We obtained approximated values of 
Vegetated lowlands

\section{Soil moisture (\% mass)}

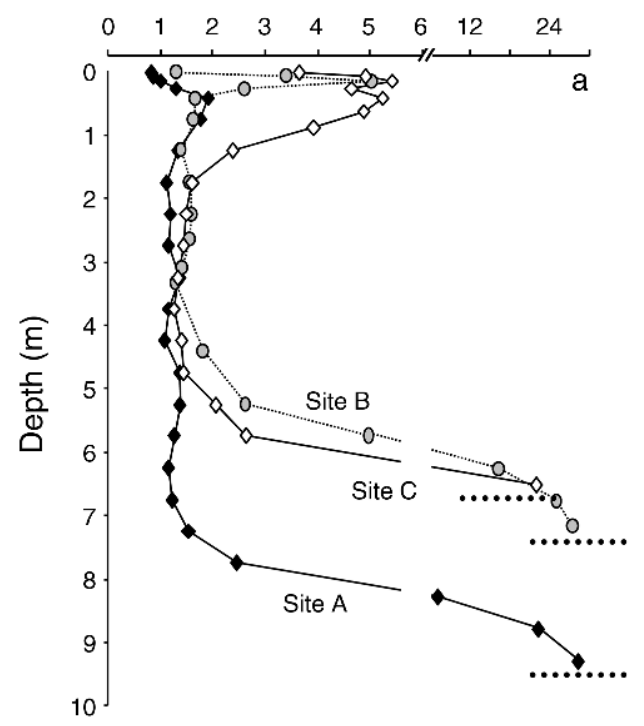

Vegetated uplands and bare lowland

Soil moisture (\% mass)

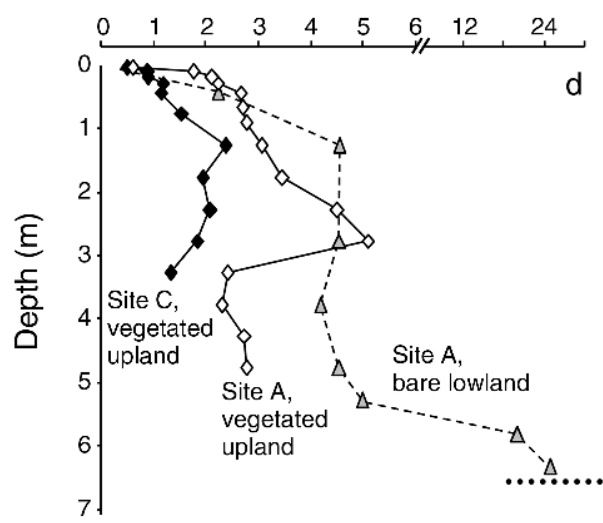

Pore water chloride ( $\mathrm{g} \mathrm{Cl} / \mathrm{L}$ )

Soil water isotopic composition, $\delta^{18} \mathrm{O}(\% \circ)$
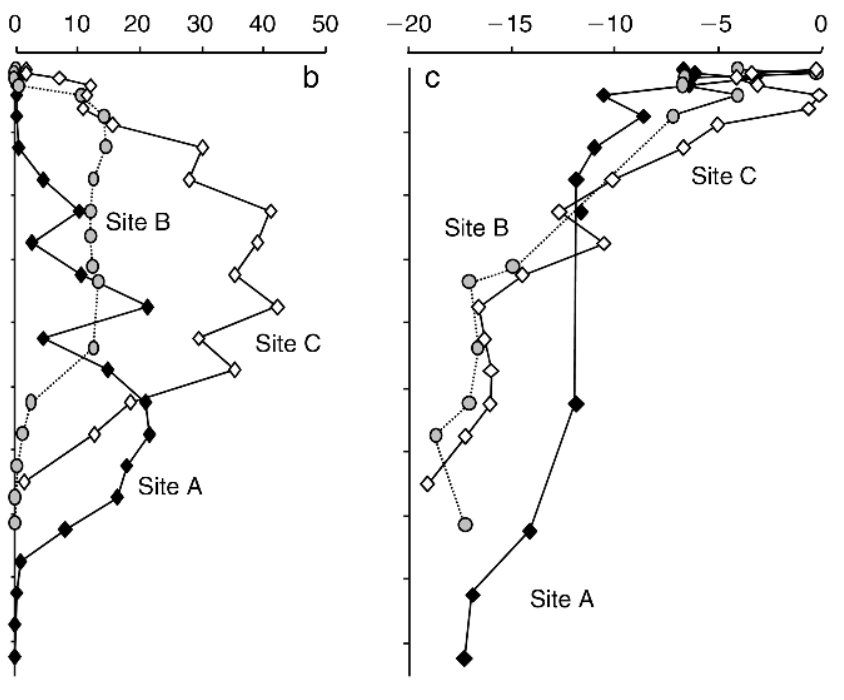

FIG. 4. Individual vertical profiles obtained at different sites and landscape positions. (a, d) Soil gravimetric moisture content. Note the interrupted $y$-axis expanding the range toward saturation values achieved in the capillary fringe. The position of the water table at each profile is indicated with horizontal dotted lines. (b, e) Pore water chloride concentration. Note the different $x$-axis scales for panels (b) and (e). (c, f) Isotopic composition $\left(\delta^{18} \mathrm{O}\right)$ of soil water.

residual downward moisture fluxes $\left(J_{\mathrm{R}}\right)$ and chloride turnover (Phillips 1994), for the $0-2.5 \mathrm{~m}$ depth interval based on our measurements of chloride and water content in soils and rainfall. These estimates were only applied to dune crests and slopes located $>14 \mathrm{~m}$ above the water table, whereas locations with shallower groundwater were excluded due to the confounding effects of its chloride contribution to soil profiles. We estimated turnover times of 26-61 yr and deep-drainage ranges of $0.11-0.5 \mathrm{~mm} / \mathrm{yr}$ in crests and slopes.

Observations in deeper soil profiles (Fig. 4) complemented those along the transects, allowing a more careful interpretation of vertical water transport. Deep profiles from the uplands of sites $\mathrm{A}$ and $\mathrm{C}$ displayed low chloride storage down to the maximum sampling depth (Fig. 4e) and, in agreement with the transects, indicated very low downward water transport, with chloride stocks of $44.1 \pm 3.9$ and $14.5 \pm 1.7 \mathrm{~g} / \mathrm{m}^{2}$ (mean \pm SD), turnover times of 387-462 and 123-156 yr, and approximate recharge rates of $\sim 1.5$ and $\sim 0.2 \mathrm{~mm} / \mathrm{yr}$ at sites $\mathrm{A}$ and $\mathrm{C}$, respectively. Chloride accumulation under vegetated dune bottoms was two to three orders of magnitude higher than in neighboring uplands (Fig. 4b) (chloride stocks of $1460 \pm 74,1492 \pm 76$, and 4351 $\pm 222 \mathrm{~g} / \mathrm{m}^{2}$, at sites A, B, and C, respectively). At these landscape positions, groundwater salt inputs associated 
with water uptake and salt exclusion by plants, had likely inflated vadose salt stocks, as suggested by chloride turnover time estimates that, based solely on atmospheric inputs (13900, 14200 , and 41400 years at sites $\mathrm{A}, \mathrm{B}$, and $\mathrm{C}$, respectively), exceed the age of sediments ( $\sim 4000$ years; Tripaldi and Forman 2007). In contrast with vegetated lowlands, the bare-dune lowland had lower chloride concentrations, with some values along the profile falling below the detection limits of our measurements (Fig. 4e) and the total chloride storage accounting for $<5 \mathrm{~g} / \mathrm{m}^{2}$. Overall, the combination of transects and deep profiles suggested that across sand dune landscapes, groundwater recharge rates are very low in vegetated crests and slopes and virtually nil in vegetated (but not in bare) dune bottoms, whereas groundwater discharge seems to be significant in dune bottoms.

\section{Vertical water and isotopic patterns across stands}

Deep soil profiles provided a stand-level perspective on the distribution of plant available moisture of atmospheric and phreatic origin. Volumetric water content in soil samples, excluding those from the top meter and from the capillary fringe, had well-defined minimum and maximum limits at $1.8 \%$ and $6.1 \%$, suggesting that these values could be used as boundaries for plant-available water in these soils of highly homogeneous texture. Profiles in vegetated lowlands showed variable moisture contents in the top $150 \mathrm{~cm}$, perhaps associated with the different sampling dates, but a consistently dry zone (volumetric moisture $\sim 2 \%$ ) was observed below this depth down to the top of the capillary fringe. Soil moisture increased below 5-7 m once the top of the $\sim 1.5$-m-thick capillary zone was reached (Fig. 4a). These dry zones located between $1.5 \mathrm{~m}$ and $4.5 \mathrm{~m}$ depth separated soil moisture pools of contrasting isotopic composition in the top, where heavier isotopic values were closer to those in rainfall, with those in the capillary fringe, which had lighter values similar to those found in groundwater (Fig. 4c). The two profiles sampled in vegetated uplands had higher moisture contents than heir lowland counterparts (Fig. 4d). Isotopic data, available only for one of these upland profiles, showed a heavier composition within the range of rainfall inputs (Fig. 4f). The profile at the bare-dune lowland was wetter (gravimetric moisture $\sim 4.5 \%$ ) between the first meter and the capillary fringe (Fig. 4d) and its isotopic composition was within local rainfall values, supporting the hypothesis that this particular landscape situation experiences recharge by local precipitation (Fig. 4f).

\section{Groundwater consumption and its imprint on water tables}

The temporal dynamics of water-table levels and the isotopic composition of plant water evidenced groundwater consumption in vegetated lowlands and allowed us to achieve two independent (yet preliminary) estimates of the magnitude of this flux, presented in this section and the next. It is important to interpret these two sources of data in the context of the phenology of the dominant lowland Prosopis trees, which displayed a consistent pattern of rapid leaf emergence in midspring (first fully expanded leaves appeared around 10 October) and a more gradual leaf senescence period that extended throughout the fall and early winter months and was likely concluded by the onset of the first frosts (Fig. 5).

Groundwater levels were very stable across years, changing less than $20 \mathrm{~cm}$ throughout our observation period, yet they showed consistent seasonal and diurnal fluctuations (Figs. 5 and 6). Diurnal fluctuations were likely associated with groundwater consumption by plants and not barometric tides, as suggested by the presence of a single nighttime high peak as opposed to the typical pattern of two peaks per day of tides (Freeze and Cherry 1979). In addition to this, fluctuations were not observed in the bare-dune well, supporting the notion that vegetation but not tides were governing diurnal groundwater-level patterns. At site $\mathrm{C}$, where groundwater levels were monitored for the longest time, seasonal patterns showing depth increases in springsummer and decreases in fall-winter, were more noticeable (Fig. 5). This pattern is consistent with high groundwater consumption after the emergence of Prosopis leaves but before the onset of rain early in the growing season, with a declining reliance on groundwater as the rain season progresses and the surface soil is rewetted (Fig. 5). Rainfall was exceptionally high in 2007-2008, and accordingly, the springsummer drop was slight and the summer-fall rise was strong.

Discharge of groundwater in woodlands was shown by sustained diurnal fluctuations of the water table (Fig. 6). Consistent patterns of nighttime increase and daytime decrease of $\sim 10 \mathrm{~mm}$ were observed in the vegetated lowlands of both sites $\mathrm{A}$ and $\mathrm{C}$ where we did detailed measurements, but not in the bare dune where plants were absent (Fig. 6). At site $\mathrm{C}$ these fluctuations were present at the beginning of all the growing seasons but took place for a longer period in the dry year of 2005-2006 (dotted lines in Fig. 5). Periods of daily level fluctuations were often interrupted by rainfall events (Fig. 6). After a rain event of $51 \mathrm{~mm}$ on 25 December 2007, the vegetated lowland at site A experienced a fast groundwater rise that could not be attributed to direct recharge but was most likely associated with a sudden interruption of discharge that allowed a sustained depth recovery and equalization with the neighboring baredune zone (Fig. 6). During the 36 months of continuous monitoring of the water-table level at site $\mathrm{C}$, we observed daily fluctuations in 12 months (one-third of the time) with an average amplitude of $8.2 \mathrm{~mm} / \mathrm{d}$ (maximum-to-minimum levels). Based on existing estimates of the specific yield of readily available water for sandy aquifers $(0.3 \mathrm{~mm} / \mathrm{mm}$, Loheide et al. 2005), we estimated a discharge rate of $296 \mathrm{~mm} / \mathrm{yr}$ at this site. 

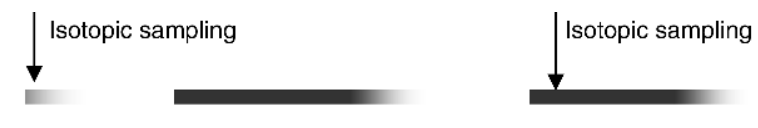

Prosopis growing season
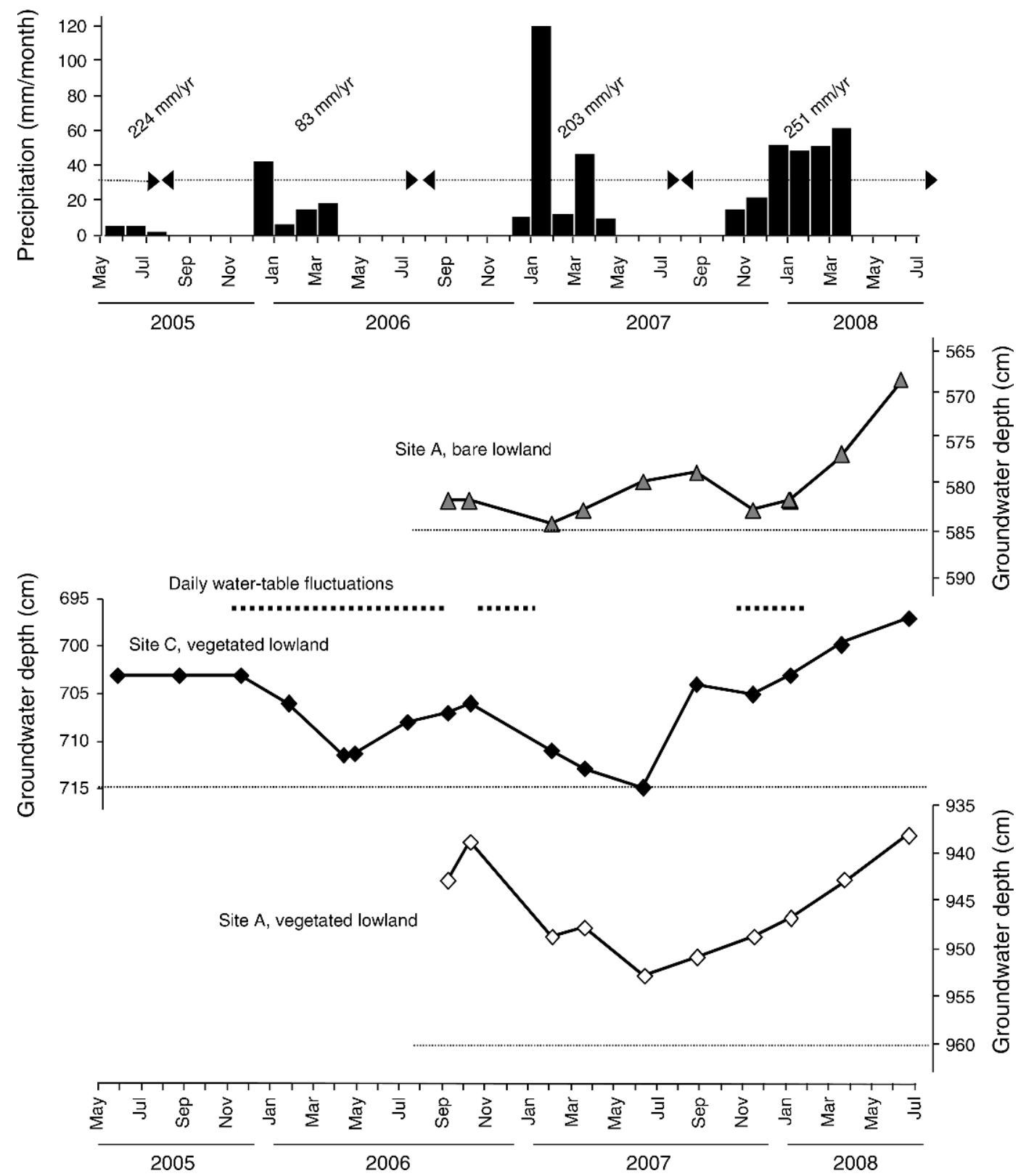

FIG. 5. Precipitation and water-table depth dynamics. Monthly precipitation values were measured at the Telteca Reserve headquarters, close to site A. Water-table depths below the soil surface were recorded periodically at boreholes located in interdune landscape positions at sites $\mathrm{A}$ and $\mathrm{C}$. Note that the $y$-axis has the same relative scale but different absolute positions. The thick horizontal bars at the top of the figure indicate Prosopis flexuosa leaf phenology, starting at the time of leaf emergence (first fully expanded leaf visible) and ending gradually at the time of leaf senescence. The horizontal dotted lines at the top of the site $\mathrm{C}$ graph indicate the periods in which daily water-table level fluctuations at site $\mathrm{C}$ were measured with a pressure transducer.

\section{Groundwater consumption and its imprint on plants}

The isotopic composition of sap water of all the species sampled at lowland positions of site $\mathrm{C}$ revealed groundwater contributions for at least some plants.
Samples taken at the end of the relatively rainy growing season of 2004-2005 (Fig. 5) indicated the following ranking of increasing groundwater use by species: Prosopis alpataco $>$ Larrea divaricata $>$ Prosopis flexu- 


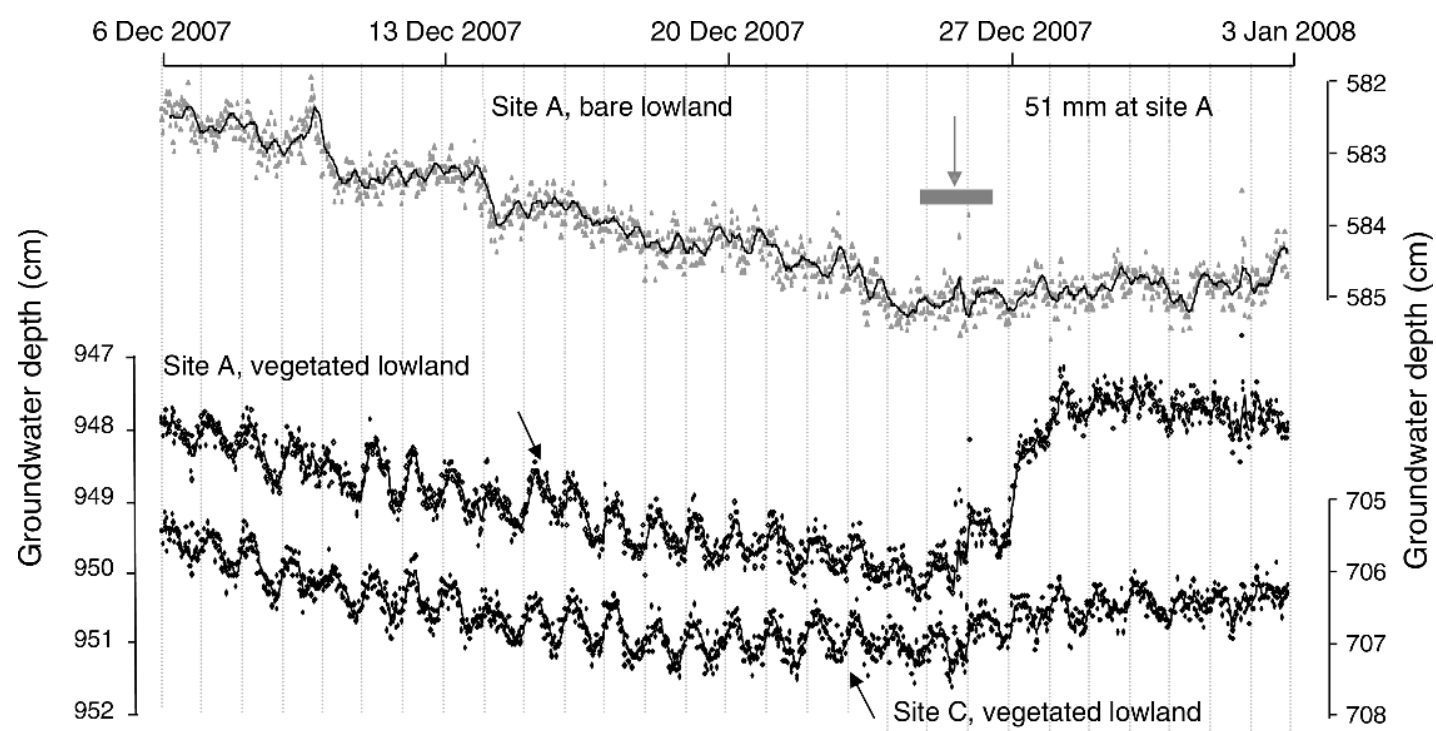

FIG. 6. Hourly dynamics of water tables captured by pressure transducers. The simultaneous variations in water-table depth at the vegetated lowlands of site $\mathrm{C}$ and the neighboring vegetated and bare-dune lowlands of site $\mathrm{A}$ are shown. The $y$-axis indicates relative depth changes and is not intended for absolute level comparisons across sites; note that the right and left $y$-axis numbers are the same scale but are offset for the different sites. Points indicate actual half-hourly measurements and lines are three-hour centered moving averages. The occurrence of a large $(51 \mathrm{~mm})$ rainfall event is depicted by a wide gray horizontal bar at the top.

osa $=$ Capparis atamisquea $>$ Bulnesia retama $>$ grasses (Fig. 7). Of all these species, only $P$. alpataco seemed to rely strictly on groundwater, whereas the rest relied at least partially on rain water. A new sampling of dominant plant species at the end of the dry season of 2006, following the very dry growing season of 20052006 (Fig. 5), showed increasing contributions of groundwater uptake (Fig. 7). At the upland positions, plant species maintained an isotopically heavier sap water composition on both sampling dates, indicating a consistent reliance on rainfall inputs (Fig. 7).

Based on the distribution of $\delta^{18} \mathrm{O}$ values from non-dry soil samples (gravimetric moisture $>1.3 \%$ ) at this site, we effectively differentiated water from the groundwater-fed capillary zone vs. the rain-fed unsaturated zone (Figs. 2 and 7). We used the mean $\delta^{18} \mathrm{O}$ values of these two water sources $(-3.5 \%$ and $-19.5 \%$ ) as endpoints of a linear mixing model, estimating groundwater contri-
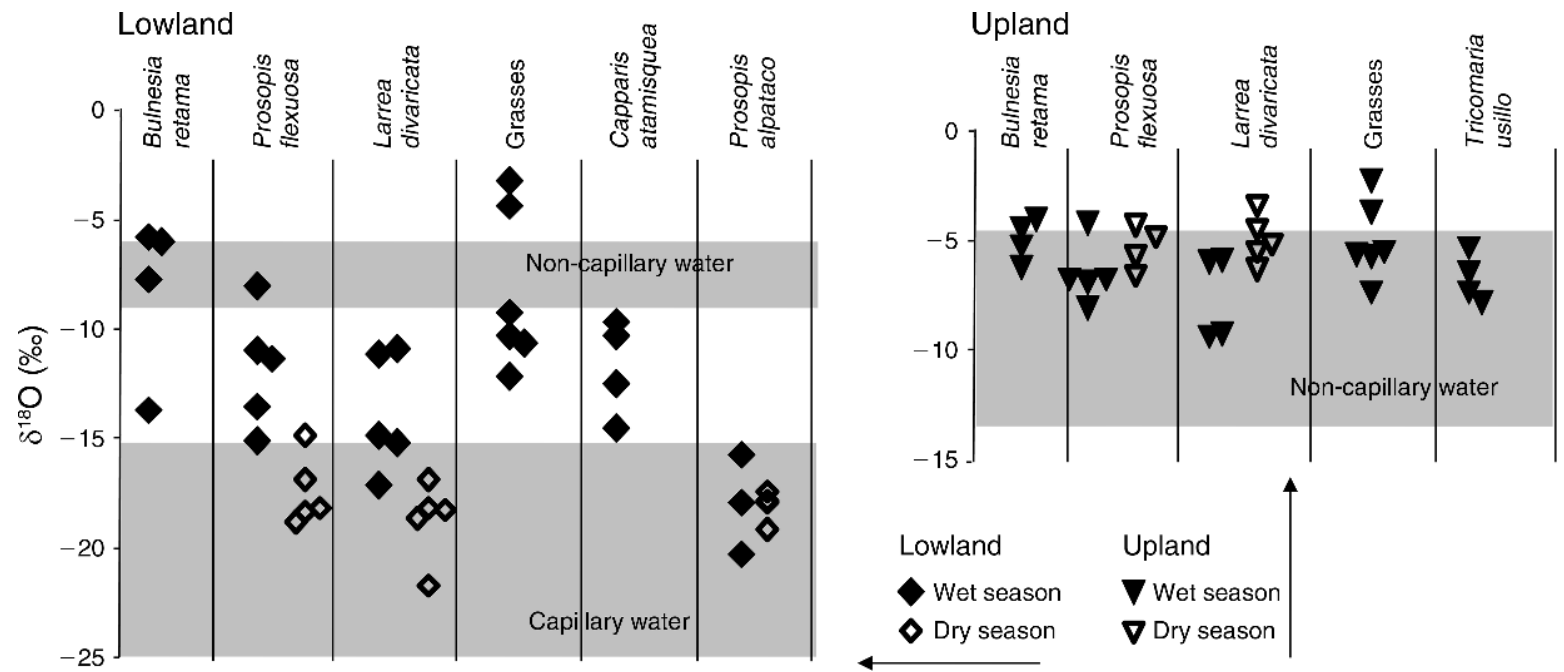

FIG. 7. Sap water isotopic composition $\left(\delta^{18} \mathrm{O}\right)$ in lowland and upland positions at site C. Horizontal gray bands represent $5-$ $95 \%$ percentiles of soil moisture $\delta^{18} \mathrm{O}$ values within the unsaturated zone (non-capillary water) and the capillary fringe (capillary water). Markers indicate sap water values of individual plants (2-3 stems per individual) grouped by species and by sampling date. The first sampling date (wet) corresponds to the end of the growing season of 2005, and the second sampling date (dry) to the end of the dry season of 2006, before the onset of the next rainfall period. 


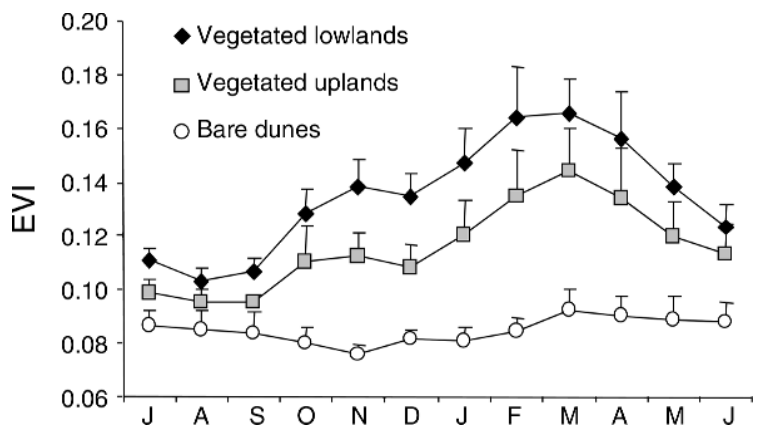

FIG. 8. Seasonal patterns of vegetation greenness (revealed by EVI, enhanced vegetation index) in Prosopis woodlands with low topographic positions $(n=6)$, shrublands with high topographic positions $(n=6)$, and bare dunes $(n=1)$. Low topographic positions were characterized by $>80 \%$ woodland coverage while high topographic positions were characterized by $>80 \%$ shrubland coverage. The mean monthly values of greenness and their interannual standard deviation throughout a seven-year period (2001-2008) are indicated. Values were obtained from the 16-day composite MODIS-EVI product MOD13Q1 with spatial resolution of $250 \mathrm{~m}$.

butions in the wet season of $100 \%, 71 \%, 61 \%, 53 \%$, and 25\% for Prosopis alpataco, L. divaricata, C. atamisquea, $P$. flexuosa, and grasses, respectively. These figures were $97 \%, 95 \%$, and $87 \%$ for P.alpataco, L. divaricata, P. flexuosa, respectively, for species sampled again in the dry season. A rough semiquantitative estimate of groundwater consumption by woodlands of $\sim 220 \mathrm{~mm} /$ yr can be made if we assume that (1) dominant Prosopis flexuosa was the only tree species, (2) it met half of its water demand with groundwater (based on its isotopic composition at the end of the wet season; see Fig. 7), and (3) all rainfall inputs in that growing season (20042005, $224 \mathrm{~mm}$ ) were consumed by the trees. While assumption (2) is conservative because we considered the sampling time with lowest groundwater contributions, assumption (3) could overestimate rainfall water uptake, and hence groundwater uptake, by ignoring the fact that part of the rainfall inputs is lost through direct soil evaporation.

Remote-sensing data revealed the imprint of groundwater consumption on the primary productivity of vegetated lowlands, as indicated by sustained higher EVI values in this stands compared to their surrounding uplands (Fig. 8). Values of EVI in the bare dune stand can be used as a baseline to estimate the relative increase of greenness of lowlands vs. uplands, which ranged between $35 \%$ in a wet year like $2007-2008$ and $99 \%$ in a dry year like 2003-2004. The same relative EVI contrasts across the growing season were highest in the first half of the growing season ( $86 \%$ for July-December) and lowest in the second half of the growing season $(50 \%$ for January-June), suggesting that across years and seasons, contrasts between lowlands and uplands increase during drier periods.
DisCUSSION

\section{Regional groundwater sources and sinks}

In response to our regional questions 1 and 2 (What are the contributions of local rainfall and mountain snowmelt to recharge? and How much groundwater is discharged through evapotranspiration?), we found that the woodlands of the Monte Desert relied strongly on a shallow phreatic aquifer recharged by Andean snowmelt waters, as suggested by isotopic, hydrologic, and biogeochemical evidence. The Mendoza River was the most likely source of groundwater recharge, conveying water from the snowfields and glaciers of the highest Andean range $(>5000 \mathrm{~m})$ to its infiltration zone $(\sim 550$ m) after a $\sim 250-\mathrm{km}$ journey that includes its passage and diversion across one of the largest irrigated oases of the continent (Fig. 1). Mountain hydrologic subsidies to arid lowlands have been identified in similar geographic settings of North America (Wurster et al. 2003) and Asia (Thomas et al. 2000, Chen et al. 2004, Gates et al. 2008). On sand dune territories, these subsidies often sustain shallow groundwater bodies that can greatly influence the geomorphological and ecological features of the landscape (Thomas et al. 2000, Chen et al. 2004).

The close isotopic match of phreatic and river waters (Fig. 2) and the lack of recharge signs in sediment cores from vegetated uplands (dominant component of the landscape), support the general view of arid and semiarid sedimentary landscapes as systems of negligible local recharge (Phillips 1994, Scanlon et al. 2006). This condition at our study area, however, was strongly tied to the presence of vegetation, since recharge occurred in the bare-dune stand. Such a combination of observations illustrates the role of natural ecosystems in preventing groundwater recharge (Scanlon et al. 2005) and highlights an often-overlooked trade-off between vegetation restoration/recovery and high-quality water recharge in arid sand dune landscapes (Wang et al. 2004, but see also Allison et al. 1985). The combination of isotopic surveys, deep soil and sediment profiles and groundwater level measurements in our study, and the application of some of these approaches in sandy deserts of North America, Asia, and Australia (Wang et al. 2004, Scanlon et al. 2005, Eamus et al. 2006, Wurster et al. 2008) suggest that groundwater-fed oases in sandy deserts typically depend more on remote water recharge than on local rainfall that would otherwise sustain only small water fluxes to phreatic aquifers.

Our results suggest that groundwater discharge from natural oases could be a regionally significant component of the water balance of deserts. Acknowledging the limited temporal and spatial extent of our data set, a rough estimate of landscape-level groundwater discharge in our study region is $18-42 \mathrm{~mm} / \mathrm{yr}$, based on the fact that woodlands occupy $9-14 \%$ of the territory, as estimated from very high spatial resolution imagery from Google Earth. These woodlands consume 200-300 $\mathrm{mm} / \mathrm{yr}$, as suggested by both water-table level fluctua- 
tions and isotopic data in our system. According to regional topographic and piezometric gradients (Departamento General de Irrigación 2004), 5800 $\mathrm{km}^{2}$ of the sand dune territory could be potentially subsidized by the Mendoza River waters and are free of surface salt accumulation, and potentially suitable for Prosopis trees to thrive. Assuming that our wholelandscape-level estimates of groundwater discharge apply to this territory, $3.3-7.7 \mathrm{~m}^{3} / \mathrm{s}$ or $7-17 \%$ of average Mendoza river flow could be consumed by groundwaterfed oases. This estimate agrees with an independent assessment based on the quantification of vegetation greenness through remote sensing (S. Contreras, E. G. Jobbágy, P. E. Villagra, M. D. Nosetto, and J. Puigdefábregas, unpublished manuscript). For comparison, irrigation today involves the diversion of $33 \mathrm{~m}^{3} / \mathrm{s}$ from this river, of which approximately one third is evapotranspired by crops and the rest lost primarily through infiltration in the transport infrastructure system and the irrigated plots (Dirección de Hidráulica 2004). In other aquifers of arid regions, phreatophytic discharge has been identified as an important water-balance component of aquifers (Scott et al. 2000, Sanderson and Cooper 2008), accounting in some cases for most of their outputs (Ostrovsky 2007). The fact that this biologically important water flux is based on remote recharge sources makes it particularly vulnerable not only to local groundwater pumping, but also to the diversion and consumption of geographically distant water sources that would otherwise feed the system (Alley et al. 2002).

\section{Groundwater use patterns}

The combination of approaches that we applied at individual sites and topographic transects allowed us to address landscape level questions 3 and 4. (What are the patterns of vertical water exchange between ecosystems and phreatic aquifers across the sand dune landscape? and How do these patterns change with topographic and vegetation cover?) Our results suggest that although phreatic aquifers can make an important contribution to the water balance of desert ecosystems, this flux depends strongly on topography and species composition. The unusually high stature, density, growth rate, and stable plant-water status of Prosopis flexuosa woodlands of the Monte Desert has been inferred to be evidence of their connection to phreatic groundwater, yet no direct proof of this link was previously available (Cavagnaro and Passera 1993, Gonzalez Loyarte et al. 2000, Villagra et al. 2005). The isotopic signatures and water-table fluctuations described here showed that woodland stands in interdune depressions relied on 6-10 m deep water tables. Deep soil profiles indicated that these stands were the only groundwater-discharging areas, whereas the uplands experienced no groundwater consumption and extremely low or no recharge (Figs. 3 and 4). While groundwater discharge in interdune depressions has been described in several sand dune landscapes under diverse vegetation types, ranging from shrublands (Muñoz-Reinoso and García Novo 2005) to annual crops (Nosetto et al. 2009), in most cases this discharge was linked to water subsidies from adjacent recharging uplands or dune crests, in what can be seen as a local flow systems (Tóth 1999). In our study region, these local contributions were most likely absent, except in the rare bare-dune stand, and phreatophytic patches are tapping a regional flow system (Tóth 1999, MuñozReinoso and García Novo 2005) that connects the Mendoza River infiltration zone with the final discharge zone at the Desaguadero River $\sim 100 \mathrm{~km}$ away and $\sim 100 \mathrm{~m}$ below its initial elevation (Fig. 1). This hydrologic setting, favoring regional lateral flow of groundwater, could explain why the net groundwater consumption of woodlands under the high water deficit of the region did not lead to an intense salinization of groundwater at the water table and capillary fringe zone (groundwater electrical conductivity $<\sim 4 \mathrm{dS} / \mathrm{m}$ ), commonly observed in flat landscapes when intense groundwater consumption sustains local flow systems that overwhelm regional hydraulic gradients and prevent horizontal salt removal (Heuperman 1999, Sapanov 2000, Jackson et al. 2005, Jobbágy and Jackson 2007).

At a more detailed scale we explored question 6 (How does the reliance on groundwater vary among plant species and seasons?). Although all of the plant species that we explored showed some degree of groundwater consumption, important differences were observed. Dominant Prosopis flexuosa trees showed an intermediate reliance on groundwater in lowlands and were present in uplands without accessing it (Fig. 7), suggesting a facultative phreatophytic behavior that favors shallow soil water uptake when available (Adar et al. 1995, Hultine et al. 2004, Engel et al. 2005). Subdominant Bulnesia retama, a more xerophytic shrub or tree with a wide distribution in uplands of the Monte Desert, showed a smaller reliance on groundwater, perhaps indicative of only occasional or opportunistic phreatophitic activity. In contrast, Prosopis alpataco shrubs revealed a complete reliance on groundwater in lowlands (Fig. 7) and were not found in the uplands, suggesting obligate phreatophytic behavior, a conclusion also supported by the localized distribution of this species on low playas and intermittently flooded areas around the region (Villagra and Roig 1999). Two puzzling findings were the high groundwater reliance of Larrea divaricata, known as a shallow-rooted shrub, and the presence of groundwater in the sap of some grasses, which are supposed to have even shallower root systems (Canadell et al. 1996, Schenk and Jackson 2002). Such results suggest that either these plants are more deeply rooted than thought, reaching the capillary fringe at $5-8 \mathrm{~m}$ of depth; or deeper-rooted individuals, such as Prosopis spp. trees (Morello 1958, Freckman and Virginia 1989), are supplying them with groundwater through hydraulic redistribution (Scholes and Archer 1997, Scott et al. 

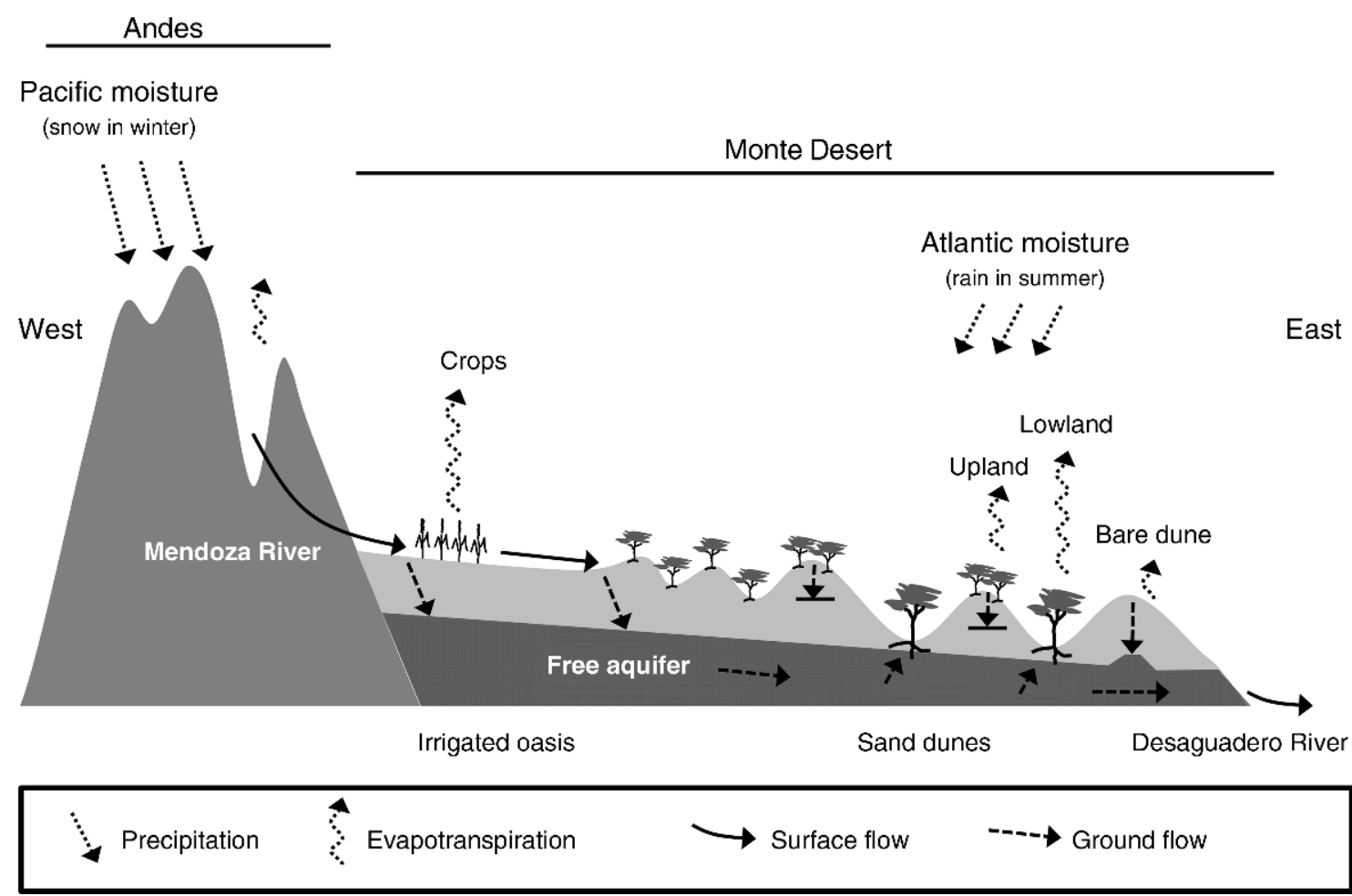

FIG. 9. Schematic representation of the study region, highlighting dominant hydrological fluxes. The west-east transect encompasses the Andean Cordillera and the Monte Desert with the irrigated oasis of Mendoza and the sand dune landscapes occupied by natural vegetation. The main findings of this work, based on isotopic surveys, deep soil profiles, and water-table records, suggest the prevalence of the hydrological fluxes indicated with the arrows. The free aquifer found under the sand dune area is recharged by the Mendoza River (Pacific isotopic signature), likely after it leaves the irrigated area. Upland vegetation is sustained by local precipitation inputs (Atlantic isotopic signature), while lowland vegetation consumes both local precipitation and remotely recharged groundwater. The free aquifer receives no local recharge in the sand dunes with the exception of the bare-dune zones, as suggested by deep soil profiles and isotopic data. The sand dune region exports a fraction of its groundwater inputs to the Desaguadero River, likely facilitating salt evacuation from the groundwater-fed oases. The onset of irrigation could have potentially compromised lowland oases by cutting the contributions of the Mendoza River to the free aquifer, causing declines in water-table level and supply to plants. However, the timing of these potential effects is unknown and needs to be resolved to project the impacts of irrigation on natural oases. Evaporative (curved lines) and liquid (straight lines) water fluxes are differentiated.

2008). The lack of groundwater consumption by plants growing in the uplands of the dune system located 15-20 $\mathrm{m}$ and $22-27 \mathrm{~m}$ above the level of woodlands and water tables, respectively, supports the notion that, although physiologically possible (Canadell et al. 1996, Haase et al. 1996), significant groundwater consumption does not occur at such depths at our sites (Zencich et al. 2002, Zeng et al. 2003). A more detailed exploration of the reliance of plants on groundwater across the dune toposequences of our study system will yield a clearer view of the relationship between groundwater depth and consumption (Nosetto et al. 2009) as well as the vulnerability of woodlands to losses in water-table levels (e.g., Cooper et al. 2006).

Regular groundwater-level monitoring provided preliminary insight into question 5 (How stable are watertable depths across seasons and years?). Seasonal variation in groundwater discharge was shown by variations in water-table depths and was likely associated with the interaction of plant phenology and climate (Fig. 5). The longest time course of water-table depth records showed a level decline starting in the spring of 2005 and 2006 at the time of leaf-out of the Prosopis trees and before the onset of the rainy season (Fig. 5). Depth declines continued throughout the rainy months. In fall-early winter, coinciding with leaf drop, groundwater levels recovered, in spite of the lack of rain. This pattern supports the idea that discharge is a strong control maintaining the stability of water levels in the study area, as found in other discharge-dominated systems (Meyboom 1967). In spite of large flow changes in the Mendoza River observed throughout our study period, particularly in its lowest section, we did not observe signs of recharge-induced level shifts, which suggests a relatively slow connection between the river and groundwater levels at our site. The comparison of vegetated vs. Bare-dune lowlands at site $\mathrm{A}$ is of particular interest in this regard, showing an earlier onset of level rise in the bare stand, more in synchrony with rainfall inputs, and suggestive of local recharge (Fig. 5). 


\section{Vulnerability of groundwater-fed oases}

Through their coupling to groundwater, ecosystems can increase their connectivity with surrounding areas (Jackson et al. 2009). This connectivity brings the possibility of water transfers from areas with excess water to areas under deficit, increasing productivity in the latter (Noy-Meir 1973). However, such connectivity also increases the vulnerability of subsidized oases to perturbations in their remote sources of water. Climate and land-use shifts in the high Andes and their footslopes, respectively, are two crucial drivers of hydrological change (Baldi et al. 2008); both of these changes could affect the health and survival of the highly productive groundwater-fed Prosopis woodlands (Fig. 8) and their associated grazing economy. Climate change is projected to decrease Pacific-born precipitation and reduce hydrological buffering by glaciers and snow, likely affecting the stability and seasonality of Andean water yields (Masiokas et al. 2006). Irrigated agriculture will likely increase its demands for water in the coming decades and is already supplementing surface-water capture with groundwater pumping. These converging pressures could compromise the supply of groundwater to natural woodland ecosystems downstream, yet the magnitude and timing of their ultimate effects are uncertain. What is increasingly evident today is that more than 150 years of irrigation from the Mendoza and San Juan rivers has already reduced natural riparian oases in the region (Abraham and Prieto 1981, Sosa and Vallvé 1999). Parallel effects on groundwater-fed oases have not been assessed, and delays imposed by the regional groundwater-flow systems need to be considered. Interestingly, signs of water-table declines are already evident in the lowest interdune depressions that we studied, where shells and gypsum deposits reveal past water tables above the surface at points where they are currently at $6 \mathrm{~m}$ depth. Constraining the timing of this groundwater drop is crucial to explore any potential link with the expansion of irrigation. Age characterization of groundwater using tritium and other anthropogenic tracers, radioisotopic dating of shells and evaporites on areas that had surface water in the past, along with dendrochronology on live and dead trees and regional groundwater modeling are some of the approaches that we are currently using to help address this challenge.

\section{Conclusion}

The presence of woodlands, which have provided critical subsistence to local settlers for centuries, within the dry conditions of the Monte Desert has puzzled scientists for decades. Our study highlights the reliance of these natural oases on phreatic groundwaters fed by Andean snowmelt (Fig. 9). By supplying these oases, Andean waters have sustained a unique culture and economy developed around shallow groundwater wells and highly productive Prosopis trees. Efforts to preserve these ecosystems and the rural communities that rely on them should focus not just on local overgrazing and logging pressures but also on possible vulnerability to hydrological alterations introduced by upstream irrigation (Fig. 9). A broader understanding of the ecohydrological coupling of mountains and deserts will enhance our ability to balance production and conservation under the growing challenges of climate and land-use change in this and other related regions.

\section{ACKNOWLEDGMENTS}

We thank Jon Karr, Julieta Aranibar, Alejandra Giantomassi, Silvina Ballesteros, German Baldi, Celina Santoni, Esteban Crespo, Sergio Contreras López, Marisa Puente, Andres Pérez Moreno, Pablo Monteverde, and Alfonsina Tripaldi for their help during field and lab activities and their valuable comments and discussions. An anonymous reviewer also provided valuable suggestions. Staff in charge of "Reserva Provincial Florística y Faunística Bosques Teltecas" offered logistical and technical support. We used the web-based GNIP (Global Network of Isotopes in Precipitation) database, provided by the Water Resources Programme of the International Atomic Energy Agency. This work was funded by the National Geographic Society (CRE-8227-07), InterAmerican Institute for Global Change Research (IAI, CRN II 2031, supported with funds from GEO-0452325 by NSF), the National Science Foundation (DEB number 0717191), and Agencia-SECyT-Argentina (PICT-200382, PICT2007-01222).

\section{Literature Cited}

Abraham, E., H. F. del Valle, F. Roig, L. Torres, J. O. Ares, F. Coronato, and R. Godagnone. 2009. Overview of the geography of the Monte Desert biome (Argentina). Journal of Arid Environments 73(2):144-153.

Abraham, E., and M. Prieto. 1981. Enfoque diacrónico de los cambios ecológicos y de las adaptaciones humanas en el N.E. árido mendocino. Cuadernos del Centro de Estudios Interdisciplinarios de Fronteras Argentinas 8:107-139.

Adar, E. M., I. Gev, J. Lipp, D. Yakir, J. Gat, and Y. Cohen. 1995. Utilization of oxygen-18 and deuterium in stem flow for the identification of transpiration sources: soil water versus groundwater in sand dune terrain. IAHS-AISH Publication 232:329-338.

Alley, W. M., R. W. Healy, J. W. LaBaugh, and T. E. Reilly. 2002. Flow and storage in groundwater systems. Science 296 : 1985-1990.

Allison, G. B., W. J. Stone, and M. W. Hughes. 1985. Recharge in karst and dune elements of a semi-arid landscape as indicated by natural isotopes and chloride. Journal of Hydrology 76:1-25.

Alvarez, J. A., P. E. Villagra, M. A. Cony, E. M. Cesca, and J. A. Boninsegna. 2006. Structure and conservative condition of the Prosopis flexuosa D. C. (Fabaceae, subfamily: Mimosoideae) woodlands in northeast Mendoza (Argentina). Revista Chilena de Historia Natural 79:75-87.

Athavale, R. N., R. Rangarajan, and D. Muralidharan. 1998. Influx and efflux of moisture in a desert soil during a 1 year period. Water Resources Research 34:2871-2877.

Baldi, G., M. D. Nosetto, R. M. Aragón, F. Aversa, J. M. Paruelo, and E. G. Jobbágy. 2008. Long-term satellite ndvi data sets: evaluating their ability to detect ecosystem functional changes in South America. Sensors 8:5397-5425.

Canadell, J., R. B. Jackson, R. J. Ehleringer, H. A. Mooney, O. E. Sala, and E.-D . Schulze. 1996. Maximum rooting depth of vegetation types at the global scale. Oecologia 108: 583-595.

Carril, A. F., M. E. Doyle, V. R. Barros, and M. N. Núñez. 1997. Impacts of climate change on the oases of the Argentinean cordillera. Climate Research 9:121-129.

Cavagnaro, J. B., and C. B. Passera. 1993. Relaciones hídricas de Prosopis flexuosa (algarrobo dulce) en el Monte, 
Argentina. Pages 73-78 in Contribuciones Mendocinas a la Quinta Reunión de Regional para América Latina y el Caribe de la Red de Forestación del CIID Conservación y Mejoramiento de Especies del Género Prosopis. Volume 1. IADIZA, Mendoza, Argentina.

Chen, J. S., L. Li, J. Y. Wang, D. A. Barry, X. F. Sheng, W. Z. $\mathrm{Gu}, \mathrm{X}$. Zhao, and L. Chen. 2004. Water resources: groundwater maintains dune landscape. Nature 432:459-460.

Cooper, D. J., J. S. Sanderson, D. I. Stannard, and D. P. Groeneveld. 2006. Effects of long-term water table drawdown on evapotranspiration and vegetation in an arid region phreatophyte community. Journal of Hydrology 325:21-34.

Craig, H. 1961. Standards for reporting concentrations of deuterium and oxygen-18 in natural waters. Science 133: $1833-1834$.

Departamento General de Irrigación. 2004. Informe de resultados de usos de la tierra según el tratamiento digital de imágenes de satellite Landsat para la provincial de Mendoza. PNUD-FAO-ARG-00/08. Gobierno de Mendoza, Mendoza, Argentina.

Devitt, D. A., D. J. Donovan, T. Katzer, and M. A. Johnson. 2002. A reevaluation of the ground water budget for Las Vegas Valley, Nevada, with emphasis on ground water discharge. Journal of the American Water Resources Association 38:1735-1751.

Eamus, D., T. Hatton, and P. Cook. 2006. Ecohydrology: vegetation function, water and resource management. CSIRO Publishing, Collingwood, Australia.

Ehleringer, J. R., S. L. Phillips, W. S. F. Schuster, and D. R. Sandquist. 1991. Differential utilization of summer rains by desert plants. Oecologia 88:430-434.

Engel, V., E. G. Jobbágy, M. Stieglitz, M. Williams, and R. B. Jackson. 2005. Hydrological consequences of Eucalyptus afforestation in the Argentine Pampas. Water Resources Research 41:1-14.

Frankenberger, W. T., M. A. Tabaitabai, D. C. Adriano, and H. E. Doner. 1996. Bromine, Chlorine and Fluorine. Pages 833-868 in S. L. Sparks, editor. Methods of soil analysis. Part 3. American Society of Agronomy, Madison, Wisconsin, USA.

Freckman, D. W., and R. A. Virginia. 1989. Plant-feeding nematodes in deep-rooting desert ecosystems. Ecology 70: 1665-1678.

Freeze, R. A., and J. A. Cherry. 1979. Groundwater. PrenticeHall, Upper Saddle River, New Jersey, USA.

Gardner, W. H. 1986. Water content. Pages 493-544 in A. Klute, editor. Methods of soil analysis. Part 1. American Society of Agronomy, Madison, Wisconsin, USA.

Gates, J. B., W. M. Edmunds, J. Ma, and B. R. Scanlon. 2008. Estimating groundwater recharge in a cold desert environment in northern China using chloride. Hydrogeology Journal 16:893-910.

Gee, G. W., and J. W. Bauder. 1986. Particle-size analysis. Pages 383-410 in A. Klute, editor. Methods of soil analysis. Part 1. American Society of Agronomy, Madison, Wisconsin, USA.

Gonzalez Loyarte, M., A. G. Rodeghiero, E. Buk, and S. Trione. 2000. Análisis comparativo de dos comunidades en el bosque de Prosopis flexuosa dc. del NE de Mendoza, Argentina. Multequina 9:75-89.

Gries, D., F. Zeng, A. Foetzki, S. K. Arndt, H. Bruelheide, F. M. Thomas, X. Zhang, and M. Runge. 2003. Growth and water relations of Tamarix ramosissima and Populus euphratica on Taklamakan desert dunes in relation to depth to a permanent water table. Plant, Cell and Environment 26:725736.

Haase, P., F. I. Pugnaire, E. M. Fernaindez, J. Puigdefaibregas, S. C. Clark, and L. D. Incoll. 1996. An investigation of rooting depth of the semiarid shrub Retama sphaerocarpa (L.) Boiss. by labelling of ground water with a chemical tracer. Journal of Hydrology 177:23-31.
Heuperman, A. 1999. Hydraulic gradient reversal by trees in shallow water table areas and repercussions for the sustainability of tree-growing systems. Agricultural Water Management 39:153-167.

Huete, A., K. Didan, T. Miura, E. P. Rodriguez, X. Gao, and L. G. Ferreira. 2002. Overview of the radiometric and biophysical performance of the MODIS vegetation indices. Remote Sensing of Environment 83(1-2):195-213.

Hultine, K. R., R. L. Scott, W. L. Cable, D. C. Goodrich, and D. G. Williams. 2004. Hydraulic redistribution by a dominant, warm-desert phreatophyte: seasonal patterns and response to precipitation pulses. Functional Ecology 18:530538.

IAEA/WMO [International Atomic Energy Agency; World Meteorological Organization]. 2006. Global network of isotopes in precipitation (GNIP). The GNIP database. 〈http://isohis.iaea.org $\rangle$

Jackson, R. B., E. G. Jobbágy, R. Avissar, S. B. Roy, D. J. Barrett, C. W. Cook, K. A. Farley, D. C. Le Maitre, B. A. McCarl, and B. C. Murray. 2005. Trading water for carbon with biological carbon sequestration. Science 310:1944-1947.

Jackson, R. B., E. G. Jobbágy, and M. D. Nosetto. 2009. Ecohydrology in a human-dominated landscape. Ecohydrology 2:383-389.

Jobbágy, E. G., and R. B. Jackson. 2007. Groundwater and soil chemistry changes under phreatophytic tree plantations. Journal of Geophysical Research-Biogeosciences 112:246261.

Loheide, S. P., II, J. J. Butler, Jr., and S. M. Gorelick. 2005. Estimation of groundwater consumption by phreatophytes using diurnal water table fluctuations: A saturated-unsaturated flow assessment. Water Resources Research 41:1-14.

Masiokas, M. H., R. Villalba, B. H. Luckman, C. Le Quesne, and J. C. Aravena. 2006. Snowpack variations in the central Andes of Argentina and Chile, 1951-2005: large-scale atmospheric influences and implications for water resources in the region. Journal of Climate 19:6334-6352.

Meyboom, P. 1967. Mass-transfer studies to determine the groundwater regime of permanent lakes in hummocky moraine of western Canada. Journal of Hydrology 5:117142.

Milner, A. M., L. E. Brown, and D. M. Hannah. 2009. Hydroecological response of river systems to shrinking glaciers. Hydrological Processes 23:62-77.

Montaña, E., L. M. Torres, E. Abraham, E. Torres, and G. Pastor. 2005. Los espacios invisibles. Subordinación, marginalidad y exclusión de los territorios no irrigados en tierras secas de Mendoza, Argentina. Región y Sociedad (Mexico) $17: 3-32$.

Morello, J. 1958. La provincia fitogeográfica del Monte. Fundación Miguel Lillo, Tucumán, Argentina.

Muñoz-Reinoso, J. C., and F. García Novo. 2005. Multiscale control of vegetation patterns: the case of Doñana (SW Spain). Landscape Ecology 20:51-61.

Naumburg, E., R. Mata-Gonzalez, R. G. Hunter, T. McLendon, and D. W. Martin. 2005. Phreatophytic vegetation and groundwater fluctuations: a review of current research and application of ecosystem response modeling with an emphasis on Great Basin vegetation. Environmental Management 35:726-740.

New, M., D. Lister, M. Hulme, and I. Makin. 2002. A highresolution data set of surface climate over global land areas. Climate Research 21:1-25.

Nichols, W. D. 1994. Groundwater discharge by phreatophyte shrubs in the Great Basin as related to depth to groundwater. Water Resources Research 30:3265-3274.

Nosetto, M. D., E. G. Jobbágy, G. A. Sznaider, and R. B. Jackson. 2009. Reciprocal influence of crops and shallow ground water in sandy landscapes of the Inland Pampas. Field Crops Research 113:138-148. 
Nosetto, M. D., E. G. Jobbágy, T. Toth, and C. M. Di Bella 2007. The effects of tree establishment on water and salts dynamics in naturally salt-affected grasslands. Oecologia 152: 695-705.

Noy-Meir, I. 1973. Desert ecosystems: environment and producers. Annual Review of Ecology and Systematics 4: $25-51$.

Ostrovsky, V. N. 2007. Comparative analysis of groundwater formation in arid and super-arid deserts (with examples from central Asia and northeastern Arabian Peninsula). Hydrogeology Journal 15:759-771.

Phillips, F. M. 1994. Environmental tracers for water movement in desert soils of the American Southwest. Soil Science Society of America Journal 58:15-24.

Rundel, P., P. E. Villagra, M. O. Dillon, S. A. Roig-Juñent, and G. Debandi. 2007. Arid and semi-arid ecosystems. Pages 158-183 in T. T. Veblen, K. Young, and A. Ormel, editors. The physical geography of South America. Oxford University Press, Oxford, UK.

Sanderson, J. S., and D. J. Cooper. 2008. Ground water discharge by evapotranspiration in wetlands of an arid intermountain basin. Journal of Hydrology 351:344-359.

Sapanov, M. K. 2000. Water uptake by trees on different soils in the Northern Caspian Region. Eurasian Soil Science 33: 1157-1165.

Scanlon, B. R., and R. S. Goldsmith. 1997. Field study of spatial variability in unsaturated flow beneath and adjacent to playas. Water Resources Research 33:2239-2252.

Scanlon, B. R., K. E. Keese, A. L. Flint, L. E. Flint, C. B. Gaye, W. M. Edmunds, and I. Simmers. 2006. Global synthesis of groundwater recharge in semiarid and arid regions. Hydrological Processes 20:3335-3370.

Scanlon, B. R., D. G. Levitt, R. C. Reedy, K. E. Keese, and M. J. Sully. 2005. Ecological controls on water-cycle response to climate variability in deserts. Proeedings of the National Academy of Sciences (USA) 102:6033-6038.

Schenk, H. J., and R. B. Jackson. 2002. Rooting depths, lateral root spreads and below-ground/above-ground allometries of plants in water-limited ecosystems. Journal of Ecology 90: 480-494.

Scholes, R. J., and S. R. Archer. 1997. Tree-grass interactions in Savannas. Annual Review of Ecology and Systematics 28: $517-544$.

Scott, R. L., W. L. Cable, and K. R. Hultine. 2008. The ecohydrologic significance of hydraulic redistribution in a semiarid savanna. Water Resources Research 44. [doi: 10.1029/2007WR006149]

Scott, R. L., J. W. Shuttleworth, D. C. Goodrich, and T. Maddock III. 2000. The water use of two dominant vegetation communities in a semiarid riparian ecosystem. Agricultural and Forest Meteorology 105:241-256.

Seyfried, M. S., S. Schwinning, M. A. Walvoord, W. T. Pockman, B. D. Newman, R. B. Jackson, and F. M. Phillips 2005. Ecohydrological control of deep drainage in semiarid regions. Ecology 86:277-287.

Small, E. E. 2005. Climatic controls on diffuse groundwater recharge in semiarid environments of the southwestern United States. Water Resources Research 41:1-17.
Sosa, H., and S. Vallvé. 1999. Lagunas de Guanacache (centrooeste de Argentina). Procedimiento de inclusión a la Convensión sobre los humedales (Ramsar, 71). Multiequina 8:71-85.

Stromberg, J. C., J. A. Tress, S. D. Wilkins, and S. D. Clark. 1992. Response of velvet mesquite to groundwater decline. Journal of Arid Environments 23:45-58.

Subsecretaría de Recursos Hídricos. 2004. Estadística hidrológica de la República Argentina. EVARSA, Buenos Aires, Argentina. [CD-ROM]

Thomas, F. M., S. K. Arndt, H. Bruelheide, A. Foetzki, D. Gries, J. Huang, M. Popp, G. Wang, X. Zhang, and M. Runge. 2000. Ecological basis for a sustainable management of the indigenous vegetation in a central Asian Desert: presentation and first results. Journal of Applied Botany 74: 212-219.

Torres, L. M. 2008. Hilos de agua, lazos de sangre: enfrentando la escasez en el desierto de Lavalle (Mendoza, Argentina). Ecosistemas (Spain) 17:46-59.

Tóth, J. 1999. Groundwater as a geologic agent: an overview of the causes, processes, and manifestations. Hydrogeology Journal 7:1-14.

Tripaldi, A., and S. L. Forman. 2007. Geomorphology and chronology of Late Quaternary dune fields of western Argentina. Palaeogeography, Palaeoclimatology, Palaeoecology 251:300-320.

Villagra, P. E., J. A. Boninsegna, J. A. Alvarez, M. Cony, E. Cesca, and R. Villalba. 2005. Dendroecology of Prosopis flexuosa woodlands in the Monte Desert: Implications for their management. Dendrochronologia 22:209-213.

Villagra, P. E., and F. A. Roig. 1999. Vegetación de las márgenes de inundación del Río Mendoza en su zona de divagación (Mendoza, Argentina). Kurtziana 27:309-317.

Wang, X.-P., R. Berndtsson, and E.-S. Kang. 2004. Water balance change for a re-vegetated xerophyte shrub area. Hydrological Sciences Journal 49:283-296.

Wilson, J. L., and H. Guan. 2004. Mountain-block hydrology and mountain-front recharge. Pages $139-158$ in F. M. Phillips, J. Hogan, and B. Scanlon, editors. Groundwater recharge in a desert environment, Southwest United States. Water Science Application Series, volume 9. American Geophysical Union, Washington, D.C., USA.

Wurster, F. C., D. J. Cooper, and W. E. Sanford. 2003. Stream/ aquifer interactions at Great Sand Dunes National Monument, Colorado: influences on interdunal wetland disappearance. Journal of Hydrology 271:77-100.

Zencich, S. J., R. H. Froend, J. V. Turner, and V. Gailitis. 2002. Influence of groundwater depth on the seasonal sources of water accessed by Banksia tree species on a shallow, sandy coastal aquifer. Oecologia 131:8-19.

Zeng, F., X. Zhang, A. Foetzki, X. Li, and M. Runge. 2003. Comparative study on the water characteristics of Populus euphratica with different depths of underground water in the foreland of Takelamakan Desert. Proceedings of SPIEThe International Society for Optical Engineering 4890:501511. 